\title{
INTERPRETATION OF RADIOMETRIC RATIOS AND MAGNETIC ANOMALIES FROM MORRO FEIO ULTRAMAFIC COMPLEX, CENTRAL-WESTERN BRAZIL
}

\author{
Adolfo Barbosa Silva ${ }^{1}$, Tiago Rocha Faria Duque ${ }^{2}$ and Felipe da Mota Alves ${ }^{3}$
}

\begin{abstract}
This study was performed to identify magnetic structures in depth and radiometric responses within and around Morro Feio Ultramafic Complex (MFUC) from the airborne geophysical (gamma-ray spectrometry and magnetic) data. Using processing techniques and profiles analysis, we have found eight gamma-ray spectrometry signatures and twenty-seven magnetic anomalies. The radiometric signatures are basically characterized by a $K$ and $e U$ relative enrichment in detriment eTh, with two of these signatures also characterized by Krelative enrichment in detriment $e U$. Based on published works, we have interpreted the radiometric responses may be from serpentinite and possible areas with hydrothermal alterations. Regarding the magnetic anomalies, we concluded that the shallowest may be the magnetic responses of dikes, contact zones and other structures, while the deepest have sources with more complex geometries and are concentrated in central-western of MFUC, where the participation of $P t$ is larger. In this aspect, the results presented reinforce the arguments favorable to existence of Pt, Crand Ni primary sources in depth.
\end{abstract}

Keywords: mineral research, airborne geophysical, serpentinites, hydrothermal alteration.

RESUMO. Este estudo foi realizado com o objetivo de identificar estruturas magnéticas em profundidade e respostas radiométricas dentro e no entorno do Complexo Ultramáfico de Morro Feio (CUMF) a partir de dados aerogeofísicos (gamaespectrometria e magnetometria aérea). Utilizando técnicas de processamento e análise de perfis, encontramos oito assinaturas gamaespectrométrica e vinte e sete anomalias magnéticas. As assinaturas radiométricas caracterizam-se basicamente por um enriquecimento relativo de $\mathrm{Ke} e \mathrm{e}$ em detrimento $\mathrm{eTh}$, com duas dessas assinaturas também sendo caracterizadas pelo enriquecimento relativo de $\mathrm{Kem}$ detrimento eU. Com base em trabalhos publicados, interpretamos que as respostas radiométricas podem ser em virtude do serpentinito e possíveis áreas com alterações hidrotermais. Com relação às anomalias magnéticas, concluímos que as mais rasas podem ser as respostas magnéticas de diques, zonas de contato e outras estruturas, enquanto as mais profundas possuem fontes com geometrias mais complexas e se concentram no centro-oeste do CUMF, onde a participação de Pté maior. Neste aspecto, os resultados apresentados reforçam os argumentos favoráveis a existência de fontes primárias de $\mathrm{Pt}$, Cre Niem profundidade.

Palavras-chave: pesquisa mineral, aerogeofísica, serpentinitos, alteração hidrotermal.

\footnotetext{
${ }^{1}$ Serviço Geológico do Brasil - CPRM, R. 148, 485 GEREMI Sala 34, 74170110, Goiânia, G0, Brazil - E-mail: adolfo.barbosa@cprm.gov.br ${ }^{2}$ TDMaps, Goiânia, G0, Brazil -E-mail: tiagorfduque@me.com

${ }^{3}$ Serviço Geológico do Brasil - CPRM, Goiânia, GO, Brazil -E-mails: felipe.alves@cprm.gov.br
} 


\section{INTRODUCTION}

Ultramafic complexes are composed of varying proportions of harzburgite, Iherzolite and dunite, usually with metamorphic textures (more or less serpentinized) and may contain important sources of $\mathrm{Zn}, \mathrm{Cu}, \mathrm{Co}, \mathrm{Ni}, \mathrm{Cr}, \mathrm{Au}$, and PGE's (Coleman, 1977; Castroviejo et al., 2004 apud Queiroga et al., 2012). In Brazil, considerable portions of the ultramafic complexes occur mainly in Tocantins Province, where about 180 ultramafic massifs have been discovered in the Goiás State since the 1970s. Some of these massifs, as the Morro Feio, were classified by Berbert (1977) as serpentinized dunite/peridotites of alpine type.

The Morro Feio is an elevation with around $940 \mathrm{~m}$ height, $4 \mathrm{~km}$ of length in northern direction, $2-2.5 \mathrm{~km}$ wide, located at northern of Hidrolândia city (30 km south of the Goiás Capital) near to BR-153 highway that connects Goiânia to São Paulo cities (Berbert \& Mello, 1969). Previous works had identified important mineral occurrence (mainly chromite, garnierite and platinum) associated to surface deposits generated by laterization and concretion process from serpentinites (Berbert \& Mello, 1969; Milliotti, 1978). However, due to the irregular character of these occurrences and the ease of exploration, the ore extractions, mainly of chromite, have been in the process of exhaustion (Valente, 1986).

Although previous works have made a detail mapping of the Morro Feio Ultramafic Complex (MFUC), such works were based on surface information, so that up today, it has not been published any research about source rocks in depth within MFUC. Such researches are import, as have already been pointed out by Berbert \& Mello (1969) when they proposed drilling holes to verify the existence of $\mathrm{Pt}, \mathrm{Cr}$ and Ni primary sources (sulfides?) in depth. Furthermore, the serpentinites may contain expressive amount of $U$ without significant enrichment in $T h$, so high $U / T h$ ratio may be expected (Deschamps et al., 2013). If these ratio values are high enough to be detected by airborne gamma-ray spectrometry data then $U / T h$ ratio may be used as an aid tool at serpentinites mapping in other research areas. This context has motivated the development of the present study.

In this study we have analyzed the airborne geophysical data (gamma-ray spectrometry and magnetic data) with the goal to identify structures and rocks in depth and their gamma-ray spectrometry signatures, mainly high $U / T h$ ratio, within and around MFUC. Our intention is to provide additional information that can complement the geological knowledge from previous studies.

\section{GEOLOGICAL SETTING}

The studied area (Fig. 1) is located in the south-center portion of the Tocantins Province. This province is a Neoproterozoic geotectonic entity developed as a result of the convergence and collision between the Amazonian, São Francisco-Congo Cratons (Dardenne, 2000; Angelim et al., 2003) and a third crustal block known as Paranapanema (Mantovani \& Brito Neves, 2009). Among the several tectonic units that compose the Tocantins Province, it is of interest the tectonic unit known as Brasilia Belt. This unit is a fold-and-thrust belt characterized by associations of supracrustal deformed rocks along the western flank of the São Francisco Craton. In the internal portion of the Brasília Belt (or meridional portion) (Dardenne, 2000; Angelim et al., 2003) outcrops the Araxá Group metasedimentary rocks. In the study area, the Araxá Group metasediments are basically formed by garnet-mica schist, quartz-mica schists and micaceous quartzite. The MFUC is hosted in these units.

Milliotti (1978) divided MFUC into five units: Antigorite Serpentinite (A1) - formed by antigorite, chrysotile and xenomorphic magnetite and leucoxene. The presence of olivine grain is doubtful; Silicified Serpentinite (A2) - corresponds to the silicified portions from serpentinites of the previous unit; Talcified Serpentinite (B1) - formed by antigorite, talc and magnetite; Talc schist (B2) - formed by talc, magnetite in euhedral porphyroblasts, antigorite, chlorite and actinolite in centimetric crystals, fibroradiated, and magnesite in porphyries; Chlorite Schist (C) - formed by chlorite, magnetite in euhedral porphyroblasts of up to $2 \mathrm{~cm}$, epidote, talc, tremolite, in fibroradiated porphyroblasts, and black tourmaline in fibroradiated porphyroblasts and euhedral.

Besides the units mentioned above, surface deposits also occur within MFUC. These deposits, basically formed by alluvium and eluvium, are important from the economic point of view, because they contain significant amounts of chromite and platinum (Milliotti, 1978). In his studies, Milliotti (1978) identified some anomalous platinum zones with values up to $1210 \mathrm{ppb}$. Based on chemical analysis of total rock, Milliotti (1978) concluded that the geological distribution of platinum and chromite is more pronounced in serpentinites (Unit A1), with the zones of contact between serpentinites and talc schist being the most concentrations of platinum and chromite. For Ni present in garnierite, Berbert \& Mello (1969) have suggested drilling holes near to the garnierite occurrence to investigate the possibility of primary sulfides in depth. 


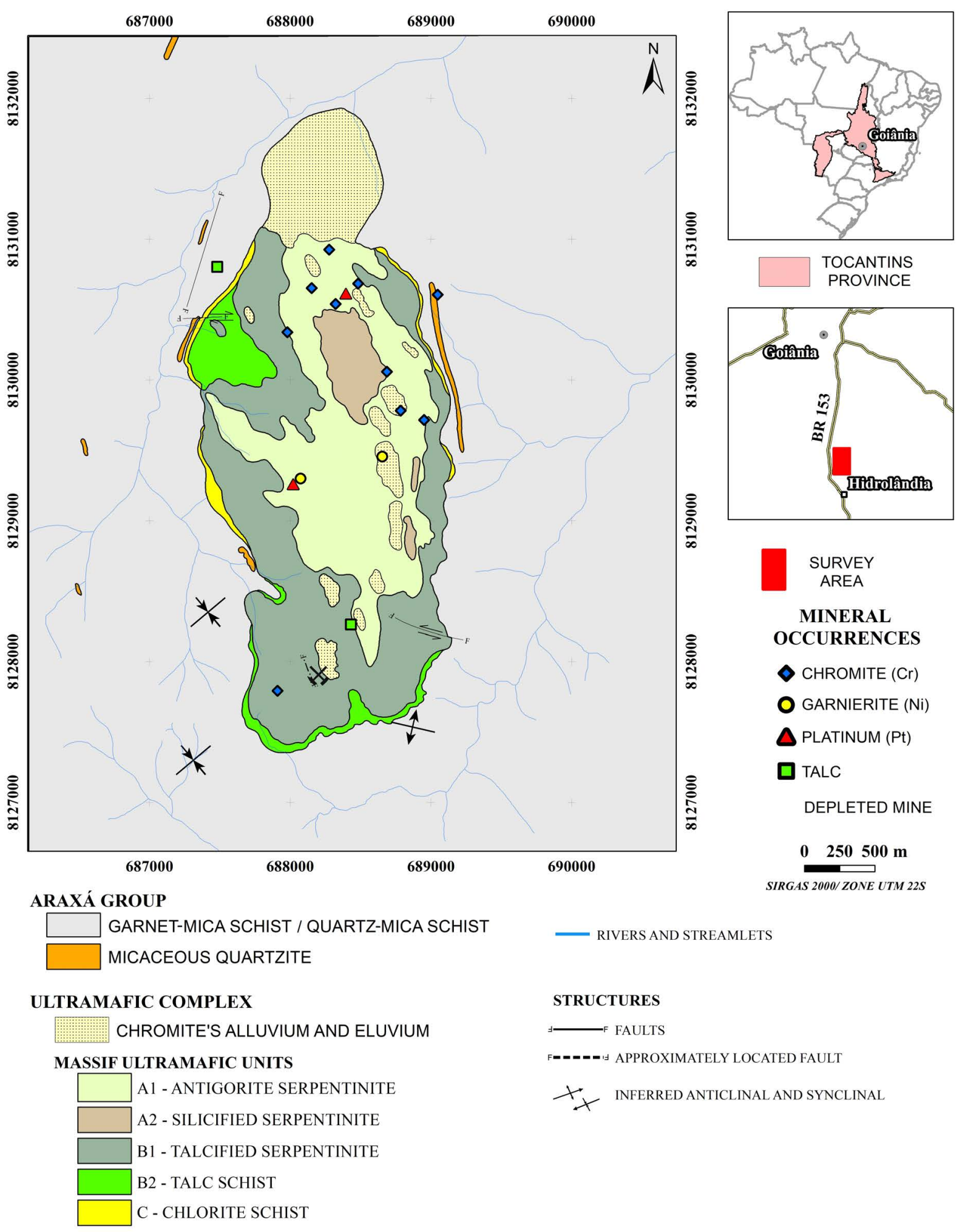

Figure 1 - MFUC Geological map and its surroundings (from Milliotti's (1978) map) presenting the mineral occurrences. The mineral occurrences were from previous maps (Berbert \& Mello, 1969; Milliotti, 1978) and obtained by GEOSGB (2018) and MRDS (2018) databases. 
Out of MFUC, Berbert \& Mello (1969) also identified a dike with direction of N30W, $3 \mathrm{~km}$ long and $100 \mathrm{~m}$ width cutting the Araxá Group rocks. The dike is composed of calcium plagioclase, pyroxenes and magnetite and ilmenite as accessory minerals.

The MFUC rocks have been interpreted by Strieder \& Nilson (1992a, 1992b) as an exotic block isolated from ophiolitic mélange in the Araxá Group garnet-mica schist. According to Deschamps et al. (2013) serpentinites from ophiolitic mélange are enriched in trace elements (LREE). These enrichments may indicate that the protoliths of the subduction-related serpentinites were enriched in a supra-subduction environment by fluids during hydration. Deschamps et al. (2013) speculated that this fluid hydration may constrain the $U$ content and led its concentration without significant enrichment in $T$, so high U/Th ratios may be observed in some cases.

\section{METHODOLOGY}

The airborne geophysical data used this work were part of the CPRM's Brasillia South Aerogeophysics Project, acquired and pre-processed in 2005 by the company Prospecting \& Engineering Lasa (LASA, 2005). The pre-processing steps consisted in the following corrections: parallax, removing diurnal variation, removing the International Geomagnetic Reference Field (IGRF), leveling and micro-levelling for airborne magnetic data and dead time, background (aircraft, cosmic and radon), height and Compton Effect and conversion to elemental concentrations for the airborne gamma-ray spectrometry data. The flight and tie lines spacings were $500 \mathrm{~m}$ in the $\mathrm{N}-\mathrm{S}$ direction and $5 \mathrm{~km}$ in the $\mathrm{E}-\mathrm{W}$ direction, respectively. The nominal terrain clearance height was $100 \mathrm{~m}$. Geosoft ${ }^{\circledR}$ Oasis Montaj ${ }^{\mathrm{TM}}$ 9.0.2 and Esri ${ }^{\circledR}$ ArcMap 10.6 softwares were used for post-processing and interpretation of airborne geophysical data, respectively. The data were projected for UTM Zone 22S coordinate system and SIRGAS 2000 datum, magnetometric and gamma-ray spectrometry data were post-processing as following below.

\section{Gamma-ray spectrometry data processing}

A statistical analysis was performed on gamma-ray spectrometry data and we identified negative values corresponding to $5.6 \%$, $5.0 \%$ and $24.4 \%$ for the potassium $(K)$, thorium equivalent $(e T h)$ and uranium equivalent $(e U)$ concentrations. Following the Grant's (1998) suggestion the negative data was kept in the database and we added a constant of 2.5 in the mentioned channels.
This procedure was intended to make all values positives in order to enable qualitative analysis based on the radioelement ratios. The addition of a constant in the mentioned channels did not affect the shape of the profiles (Fig. 2). In order to investigate which interpolation method would be the most representative of gamma-ray spectrometric data, two interpolation methods, minimum curvature (Briggs, 1974) and bi-directional (Reeves, 2005), were compared. The bi-directional method, with cell size of $100 \mathrm{~m}$, produced better results (Fig. 2). Using this method, we produced $K$, eTh and $e U$ concentration maps and $e U / e T h, K / e U$, KleTh ratio maps (Fig. 3). The airborne gamma-ray spectrometry data was also analyzed along the flight and tie lines. These lines were numbered from $P-01$ to $P-10$, with profiles from $P$ - 01 to $P-09$ corresponding to flight lines and profile $P$ 10 corresponding to tie line. The sample spacing was about 80 $\mathrm{m}$. The even profiles were oriented $\mathrm{S}-\mathrm{N}$ and odd profiles were oriented $\mathrm{N}-\mathrm{S}$, excepted to $\mathrm{P}-10$ that is oriented $\mathrm{E}-\mathrm{W}$.

In the profiles, besides $K$, eTh and $e U$ concentrations and radioelements ratios data, we also calculated and analyzed hydrothermal alteration indicators profiles like parameter $F(F P)$ (Efimov, 1978 apud Gnojek \& Prichystal, 1985) and K (KD) and eU (UD) excesses (Galbraith \& Saunders, 1983; Saunders et al., 1987; Pires, 1995). Finally, using the Seeker tool integrated to Oasis Montaj software, a $30 \mathrm{~m}$ resolution digital terrain model (DEM) grid acquired by Shuttle Radar Topography Mission (SRTM) was used to aim interpretations of gamma-ray spectrometry data. The DEM grid was sampled for gamma-ray spectrometry database with the same sample spacing $(80 \mathrm{~m})$.

\section{Magnetometric data processing}

The magnetometric data was interpolated by bi-directional method with $100 \mathrm{~m}$ cell size (Billings \& Richards, 2001; Reeves, 2005) to obtain the Anomalous Magnetic Field (AMF) grid. To facilitate the interpretation process of the magnetic anomalies, we applied the analytical signal amplitude (ASA) (Nabighian, 1972; Roest et al., 1992) on the AMF grid to highlight the magnetization contrast zones. From the ASA grid, we produced the First order Vertical Derivative (FVD), Tilt angle (TDR) (Miller \& Singh, 1994) and Total Horizontal Derivative of the Tilt angle (THDR-TDR) (Verduzco et al., 2004) grids (Fig. 4). Finally, the grids from magnetometric data were sampled for the gamma-ray spectrometry databases with the same sample spacing $(80 \mathrm{~m})$. The grids from magnetic data were also used to estimate the magnetic source depth. In this work, we used three different methods: The Standard Euler Deconvolution (SED) (Reid et al., 


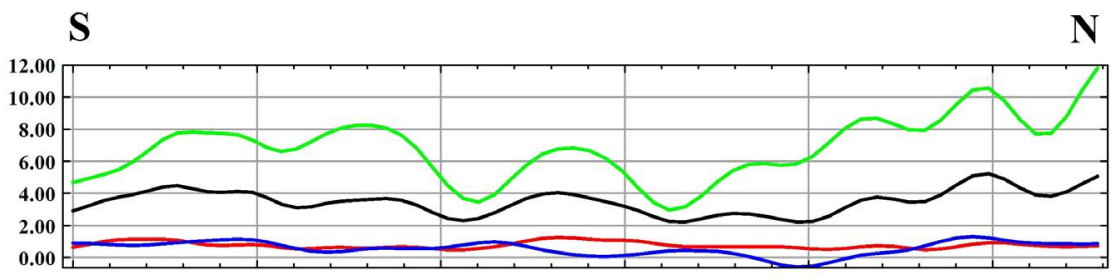

(a)

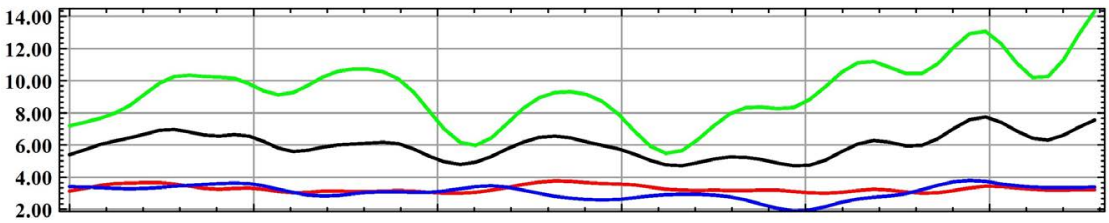

(b)

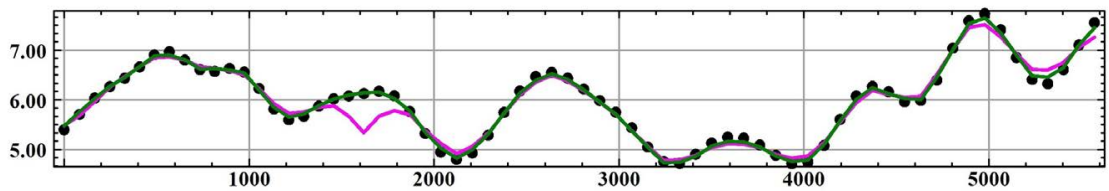

(c)

Distance (m)

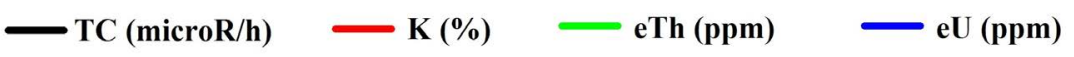

- TC - Points $\longrightarrow$ TC - Minimum Curvature $\longrightarrow$ TC - Bi Directional

Figure 2 - Profiles of the radioelement concentrations before (a) and after (b) the addition of a constant. (c) Comparison among interpolation methods applied to the total counting channel.

1990); Source Parameter Image (SPI) (Thurston \& Smith, 1997); and ASA-Euler (AN-EUL) (Salem \& Ravat, 2003).

The SED method was applied on AMF grid. We considered Structural Index (SI) values of 0,1,2 and 3. For each SI values we considered error of $5 \%$ on estimative at depth, terrain clearance height of $100 \mathrm{~m}$ and window size of 20 times the grid cell size. The SED's solutions were computed by E3DECON.GX algorithm from Oasis Montaj software. For SPI method the directional derivatives ( $x, y$ and $z$ ) were computed by gridDxDy.GX and gridDz.DX algorithms integrated to the presented software. Next, using these derivatives, the local wavenumber peak was selected by the algorithm developed by Blakely \& Simpson (1986). In this work, we used the highest restrictive selection level, which is, a peak was only selected if its value in the grid cell was greater than the values of the grid cells in the four adjacent directions. The solutions SPI were calculated by algorithm SPI.GX of the SPI package also integrated to the mentioned software. Finally, for AN-EUL method, the position of the center of the anomalous source was founded based on the maximum of the ASA which was selected through the algorithm Get a Grid Location of the Euler3D package also integrated to Oasis Montaj software. The selection level was the same as selected in the SPI method with an addition of a cutoff value of $0.01 \mathrm{nT} / \mathrm{m}$. Selected peaks below this threshold were rejected. After the selection of ASA maxima, the Located AN-EUL algorithm was used to compute the structural index and depth estimates based on Salem \& Ravat's (2003) equations.

For the depth estimate obtained by SPI and AN-EUL method, only solutions located 100 meters distant from identified magnetics anomalies were selected, while for SED method all solutions were considered.

\section{RESULTS}

The maps produced from airborne geophysical data show that MFUC has some distinctive radiometric and magnetic responses regarding to the rocks surrounding (Figs. 3 and 4). The MFUC rocks show low $K$, eTh and $e U$ concentration (Figs. 3a - 3c), 

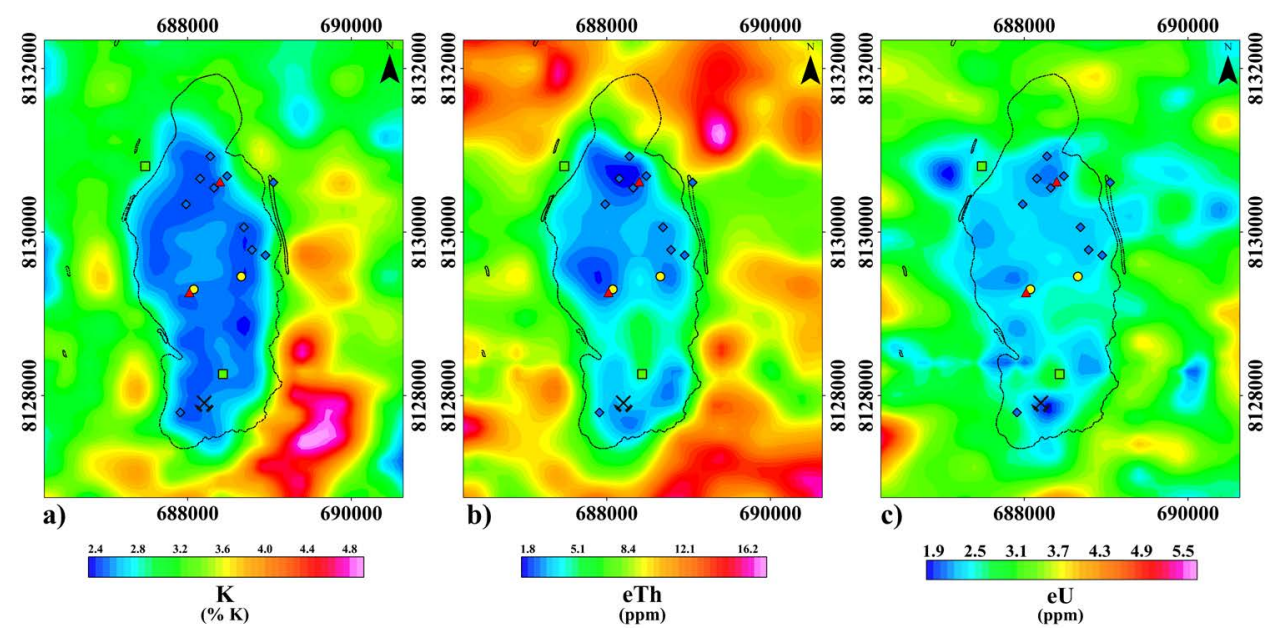

b)

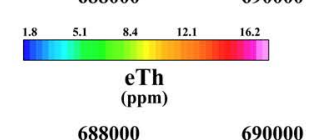

c)
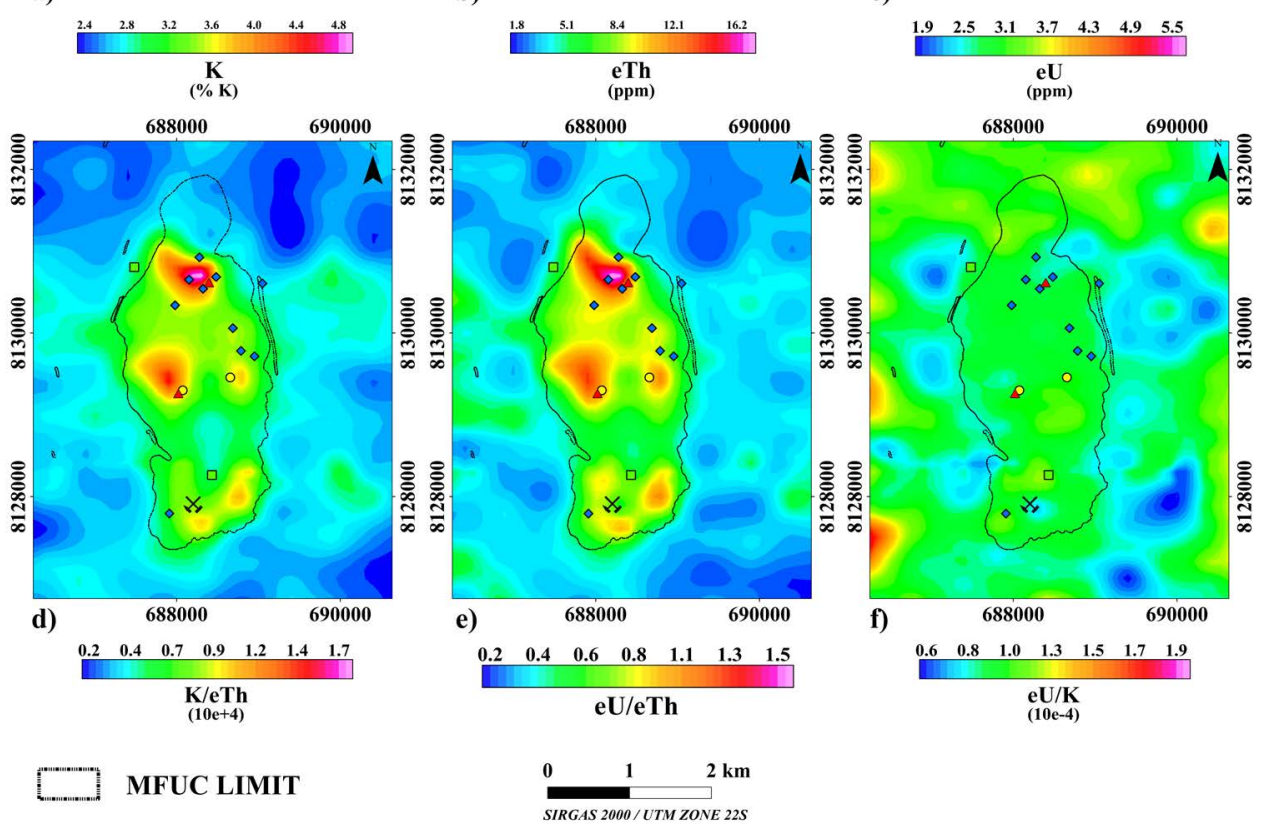

MFUC LIMIT

Figure 3 - MFUC Radiometric maps. a) Percentage of ${ }^{40} K$; b) Thorium equivalent concentration (measures of ${ }^{207} T$ ); c) Uranium equivalent concentration ( ${ }^{214} \mathrm{Bi}$ measurements); d), e) and f) $\mathrm{K} / \mathrm{eTh}, \mathrm{eU} / \mathrm{eTh}$ and $\mathrm{K} / \mathrm{eU}$ ratios, respectively. The mineral occurrences symbols are the same of Figure 1.

but the radioelement ratio maps outlined a few zones inside the MFUC with an evident enrichment of $K$ and/or eU close to mineral occurrences (Figs. $3 d-3 f$ ). In the maps of Figure 4a, the MFUC shows a complex magnetic anomaly, with two positive poles around a central negative. This complex anomaly is due to the magnetic sources of MFUC are near the magnetic equator (the inclination was about $-22.71^{\circ}$ in the year 2005). In Figure 4, we identified zones within MFUC with magnetization contrasts. As well as radiometric ratio maps, we observed these zones are also close to mineral occurrences. To study these zones in more detail, we have analyzed the airborne geophysical data in profile (P01 - P10) (Figs. 6, 7, 8, 9b and 10) and it was possible to identify eight (G1 - G8) and twenty seven (M1 - M27) regions with different gamma-ray spectrometry and magnetic responses, respectively. The Figure 5 shows an example of our procedure in the identification of the airborne geophysical responses previously mentioned. The profile locations were plotted in the map of Figure 11. Airborne geophysical responses have not been identified based our proceeding only for $\mathrm{P}-07$ (Fig. 9a).

In all cases, the gamma-ray spectrometry responses are characterized mainly by decrease in eTh concentration curve in 


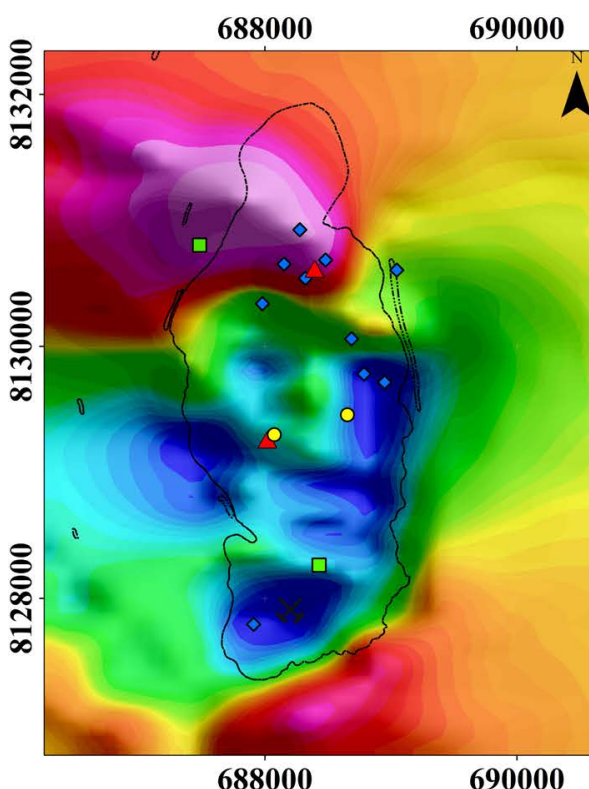

a)
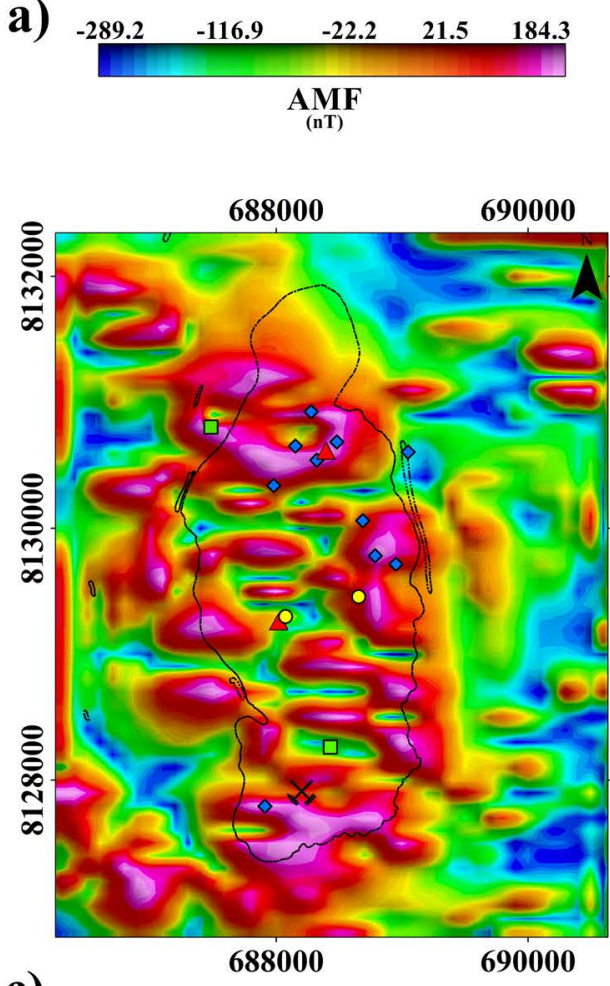

c)

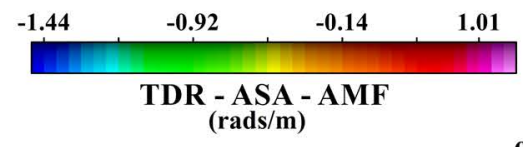

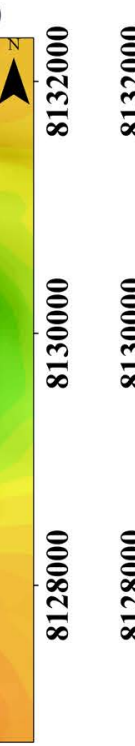

b)

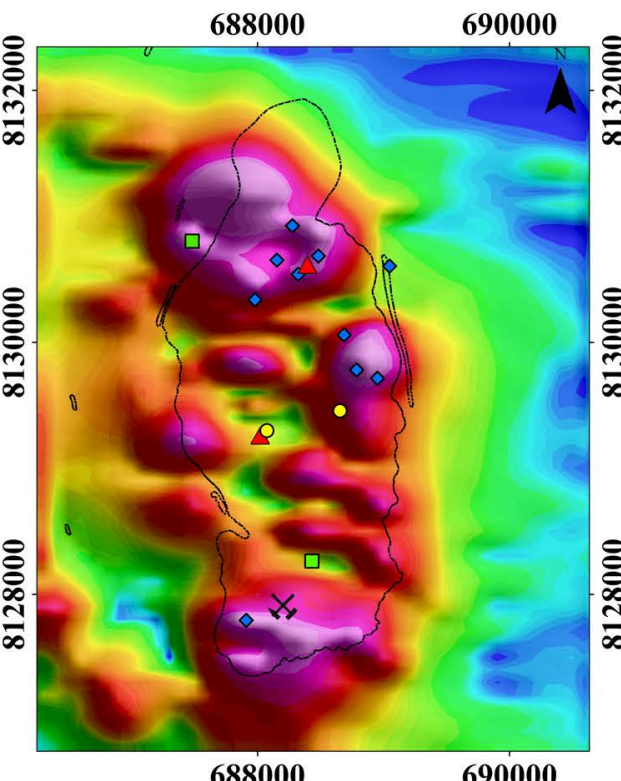

))

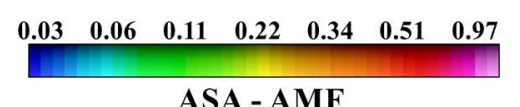

ASA - AMF

(nT/m)

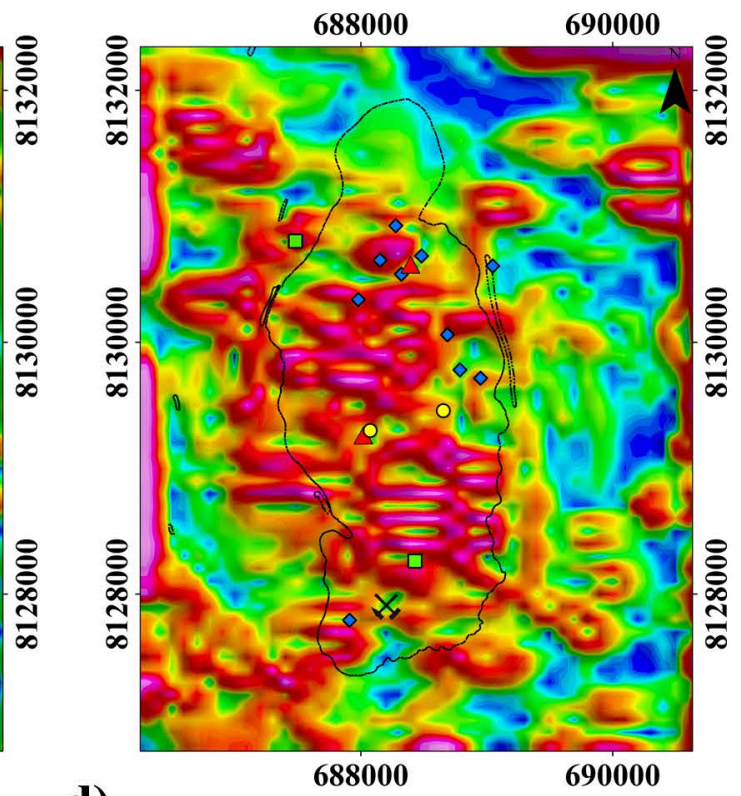

d)

$\begin{array}{llllllll}0.001 & 0.002 & 0.003 & 0.004 & 0.006 & 0.008 & 0.014\end{array}$

THDR - TDR

$\left(\operatorname{rads} / \mathrm{m}^{2}\right)$
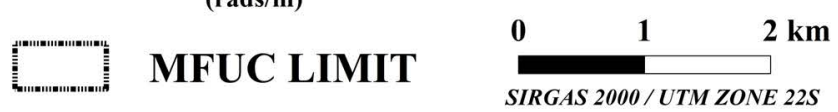

Figure 4 - Magnetometric maps. a) AMF; b) ASA from AMF; c) Tilt Angle of ASA-AMF; d) THDR of Tilt Angle from ASA-AMF. The mineral occurrences symbols are the same of Figure 1. 

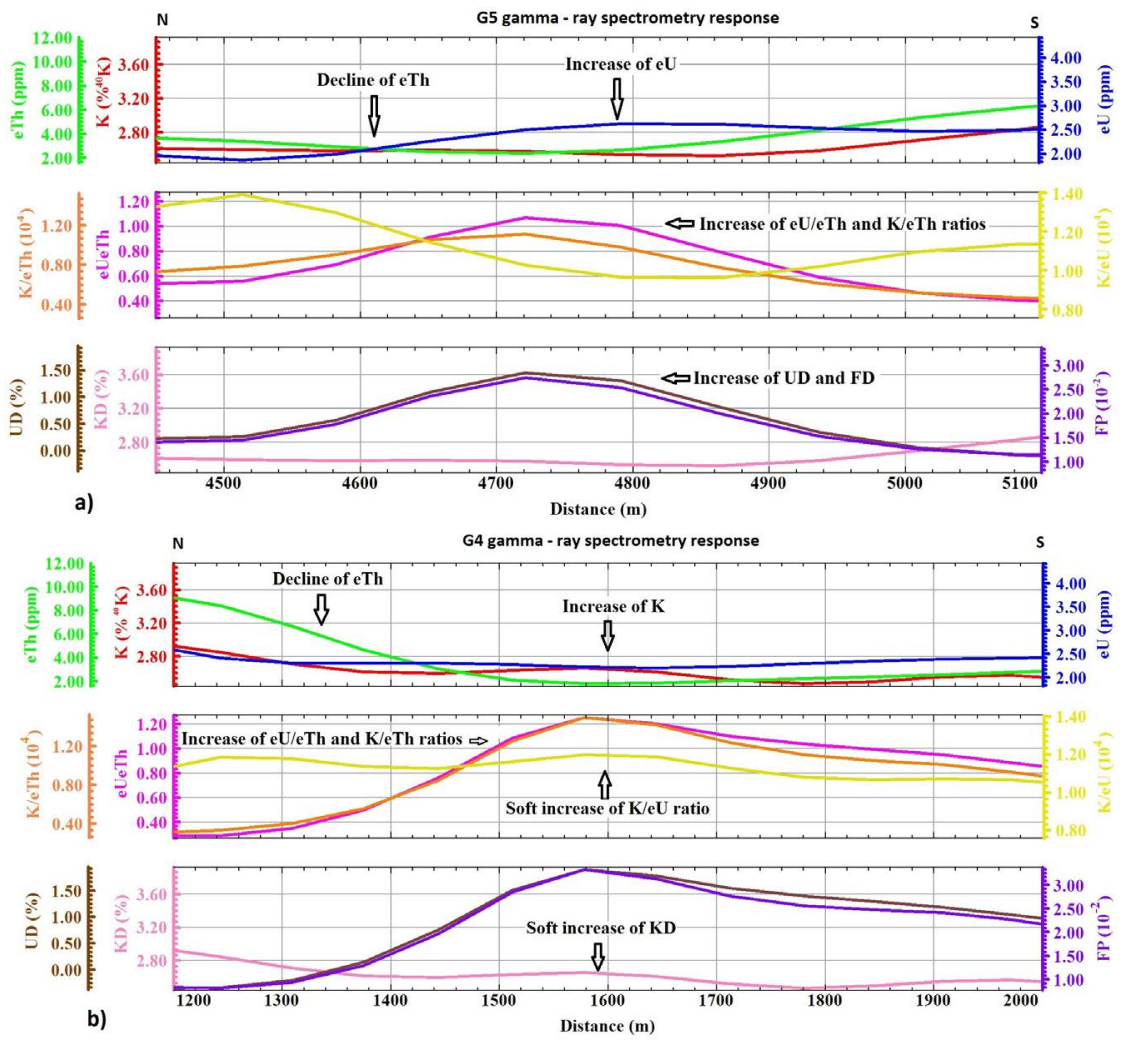

M19 Magnetic Anomaly

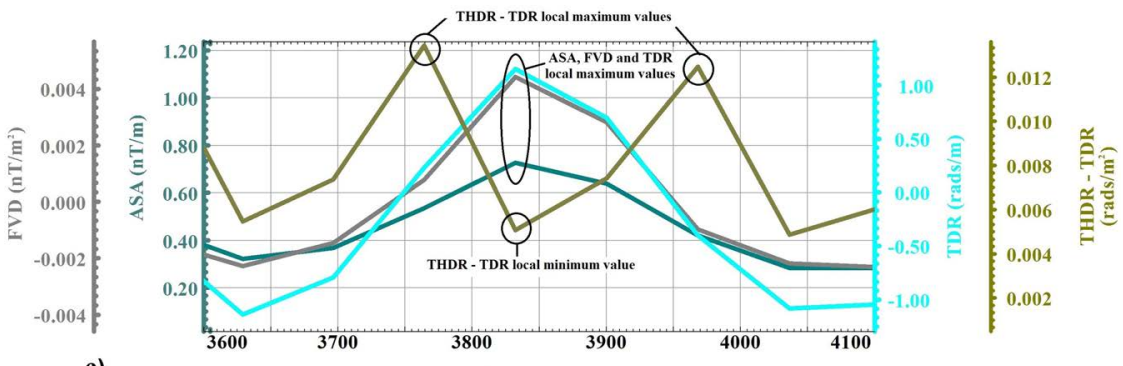

c)

Distance (m)

Figure 5 - Procedure used to identify the gamma-ray spectrometry responses and magnetic anomalies. a) Detail of G5 gamma-ray spectrometry response. The G1, G3, G6, G7 and G8 have shown the same gamma-ray spectrometry response of G5. b) Detail of G4 gamma-ray spectrometry response. Only G2 has shown the same gamma-ray spectrometry response of G4. c) Detail of M19 magnetic anomaly showing the procedure used to identify the magnetic anomalies. The G5, G4 and M19 airborne geophysical responses are presented in profile of Figure 8a.

according to an increase in $K$ and/or $e U$ concentrations curves. This behavior of the radiometric elements is highlighted on eU/eThand K/eThratios curves, where is also possible to observe a correlation among positive peaks from $e \mathrm{U} / \mathrm{eTh}$ and $\mathrm{K} / \mathrm{e}$ Th ratios and FP and UD (Figs. 5a and 5b and Figs. 7, 8 and 10). The KD curves showed a soft increase only in G2 (Fig. 7b) and G4 (Fig. 8a). For these regions, the $K$ concentration and $K / e U$ curves also showed a soft increase, following eU/eTh, FD and UD curves. Based on eU/eTh, K/eTh and FD peaks, we plotted all radiometric regions (G1 - G8) as points in the geological map of the Figure 1 (Fig. 11). In Figure 11, all the gamma-ray spectrometry responses occur within MFUC. The G1, G3, G6 and G8 areas are in B2 unit (talcified serpentinites), while remaining areas are in $A 1$ unit (antigorite serpentinites). In addition, the majority of them occur in steep relief, except G7 area that appears to be located in relatively flat relief. Regarding the mineral occurrence locations, only G2 and G4 areas occur less than $200 \mathrm{~m}$ apart to platinum, chromite and garnierite occurrences. 

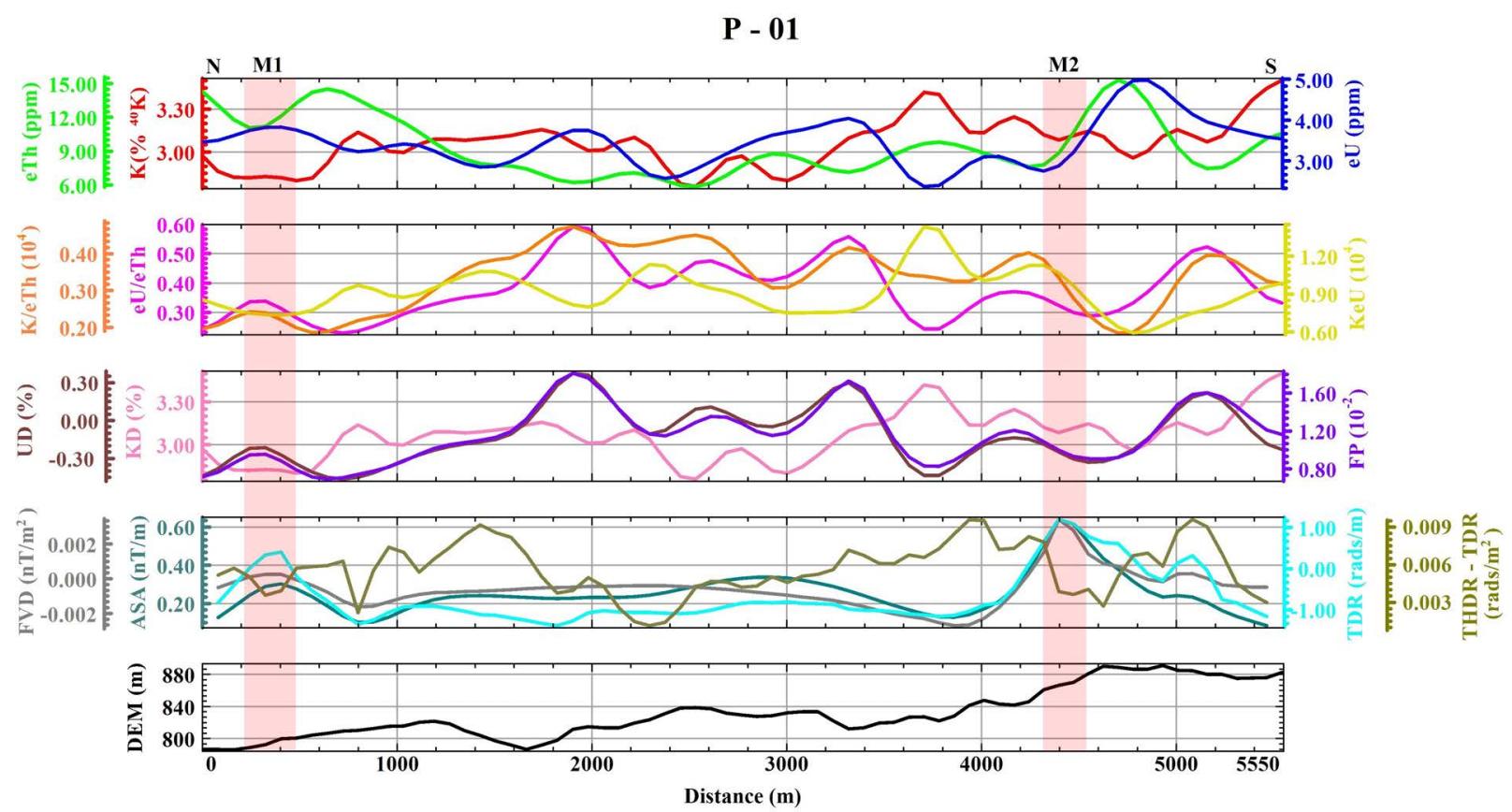

(a)

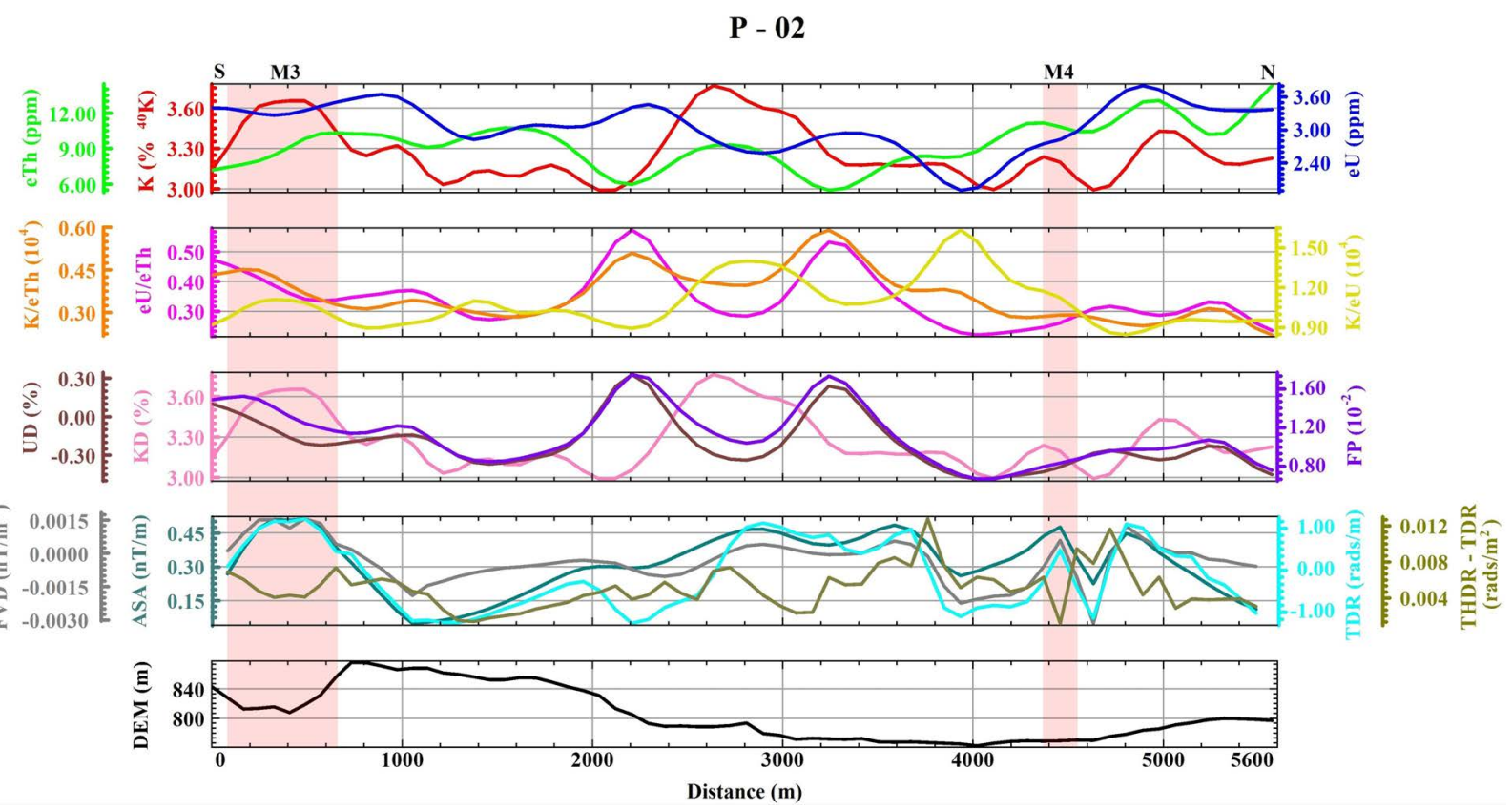

(b)

Figure 6 - Airborne geophysical responses that have been identified in: a) P - 01 profile and; b) P - 02 profile. The gamma-ray responses are highlighted in light grey and magnetic anomalies are highlighted in light pink. 


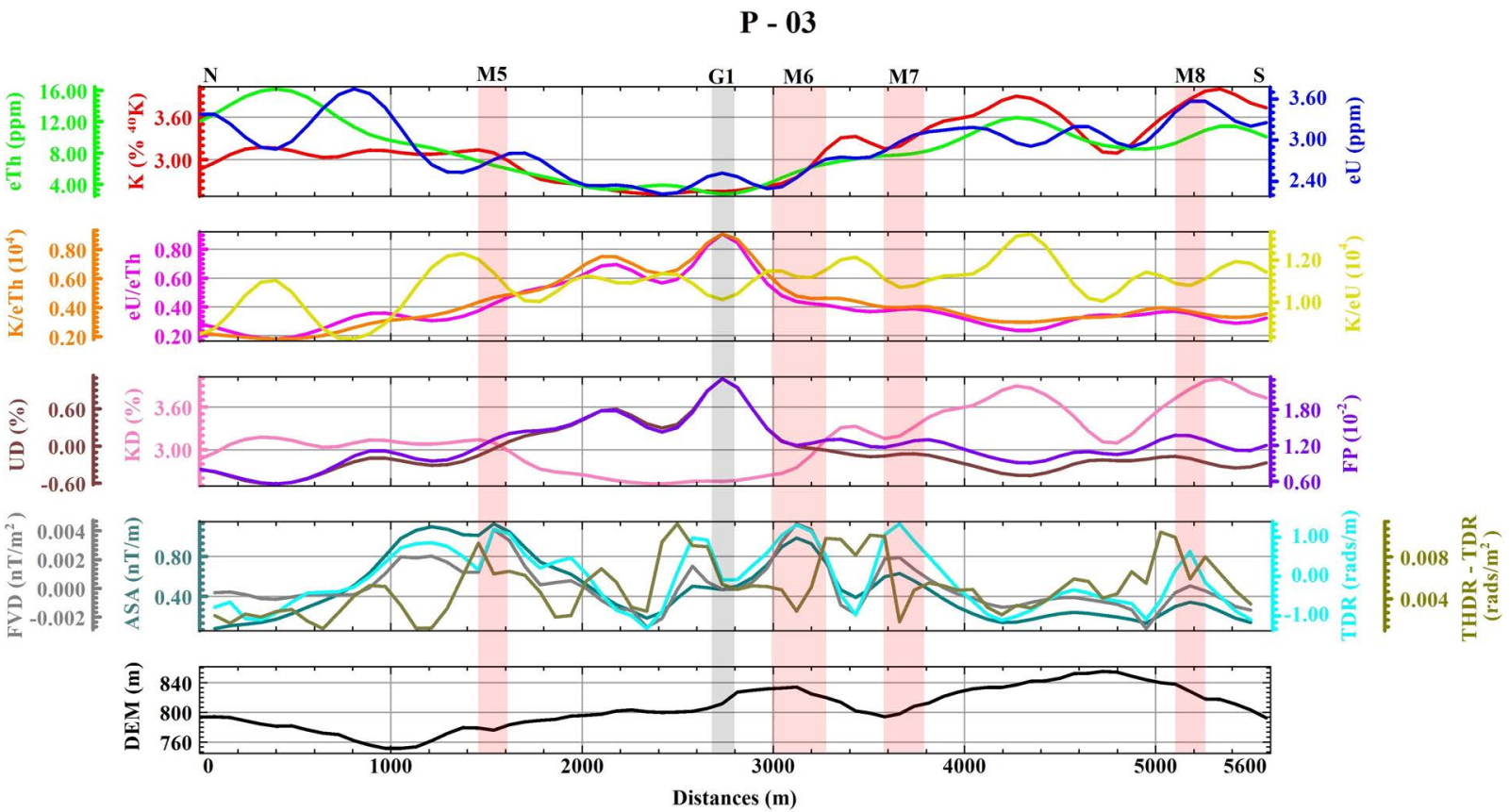

(a)

\section{P - 04}

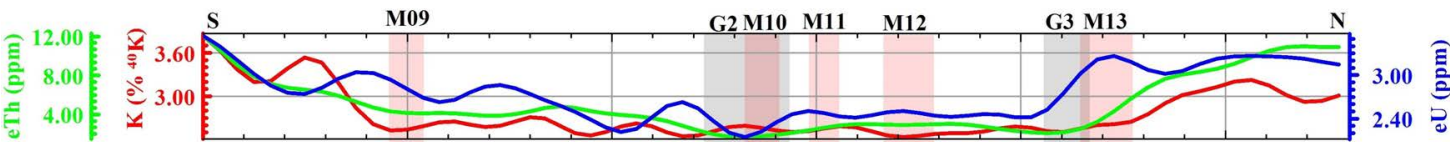

$\begin{array}{ll}\text { ¿ } & 1.20 \\ \equiv & 0.80 \\ \simeq & 0.40\end{array}$
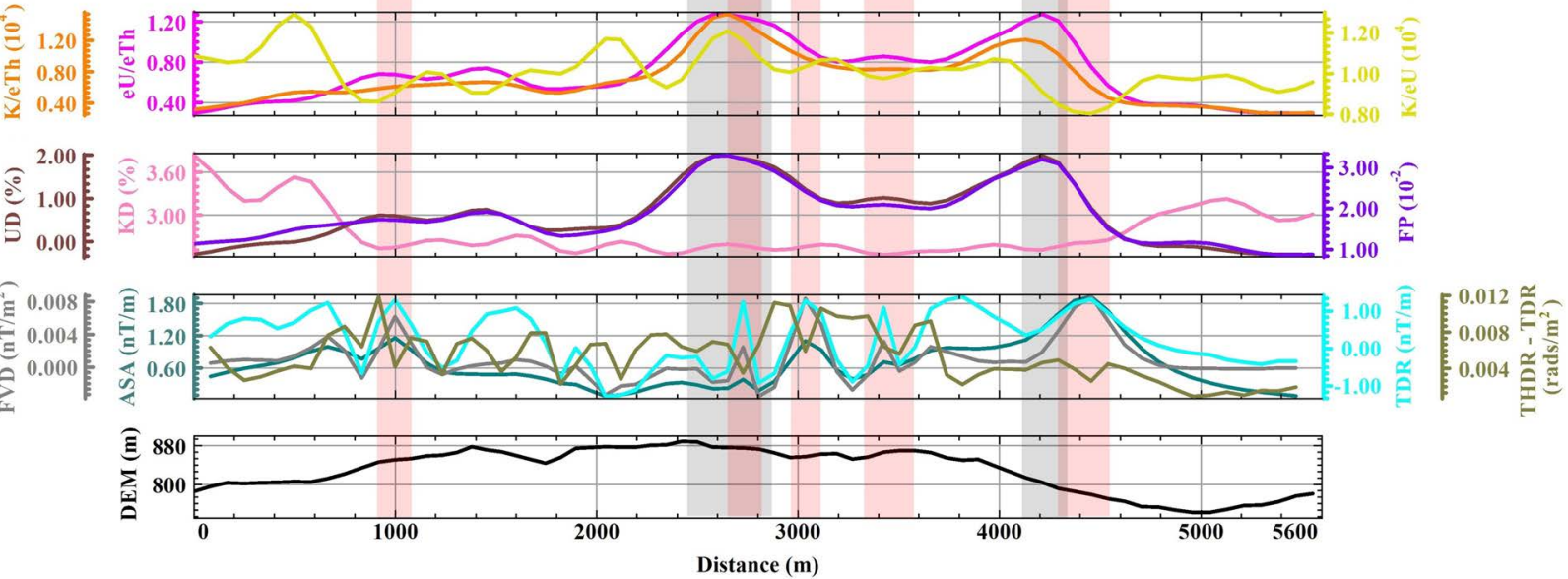

(b)

Figure 7 - Airborne geophysical responses that have been identified in: a) P - 03 profile and; b) P - 04 profile. The gamma-ray responses are highlighted in light grey and magnetic anomalies are highlighted in light pink. 


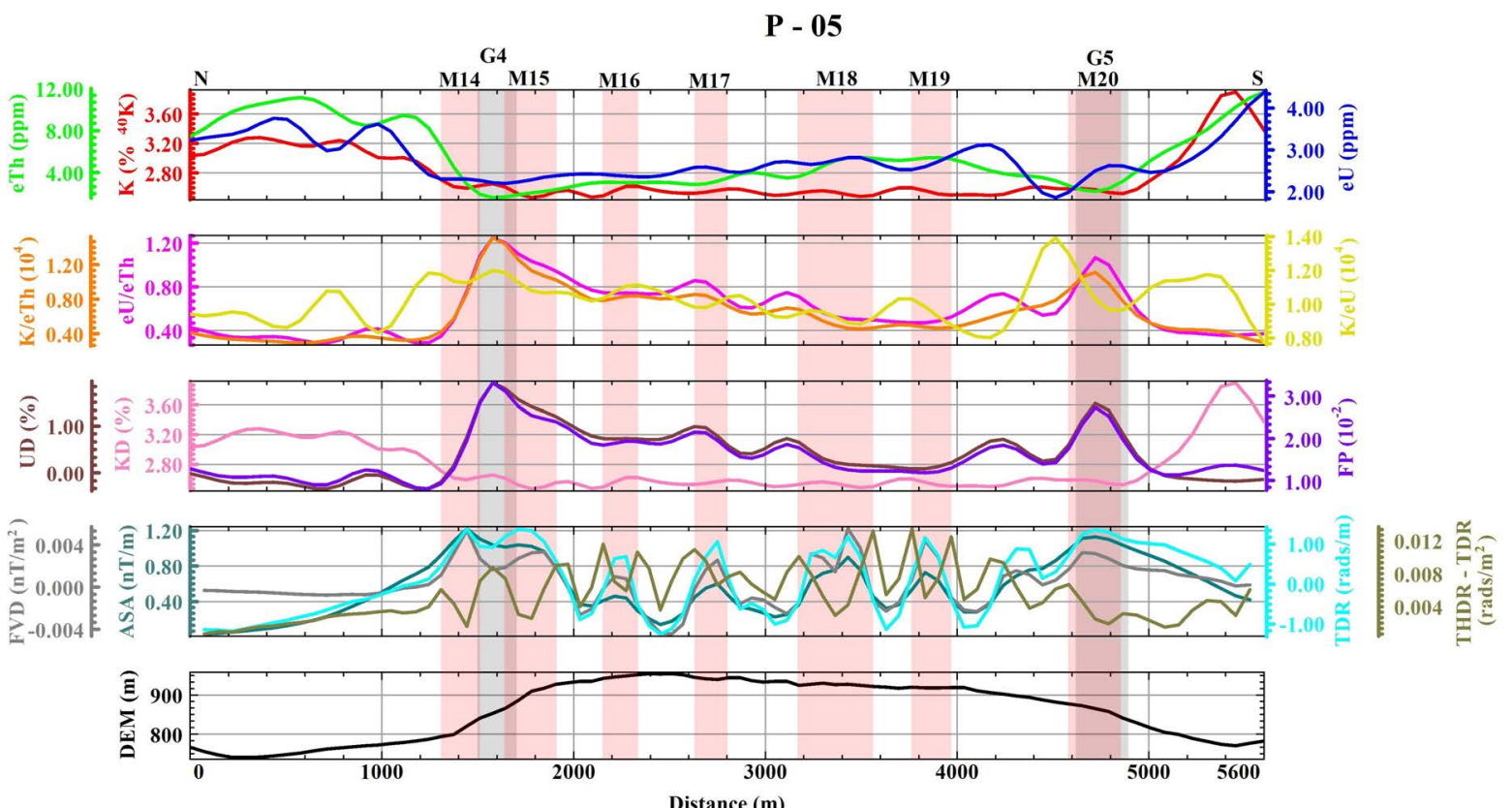

(a)

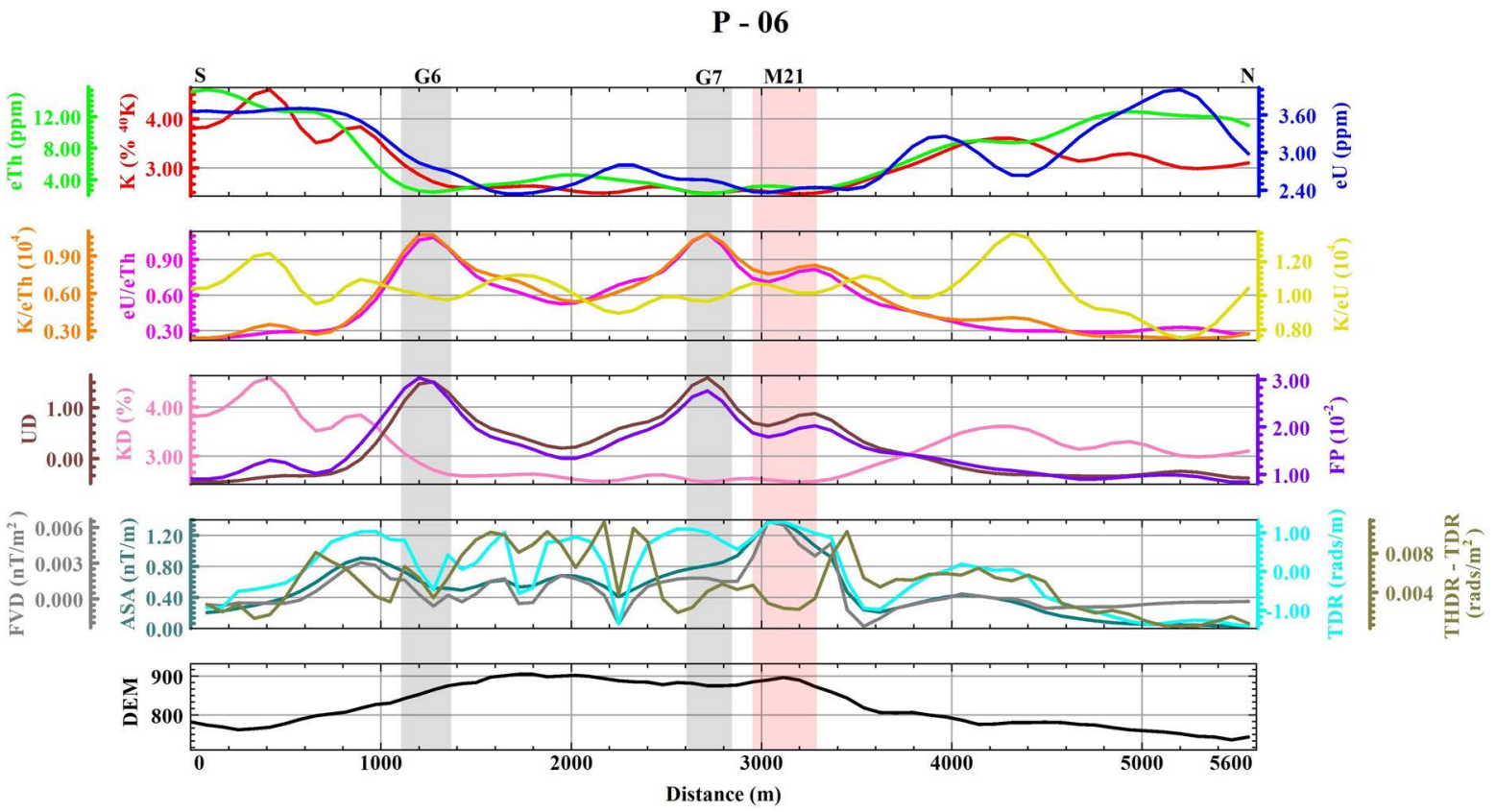

(b)

Figure 8 - Airborne geophysical responses that have been identified in: a) P - 05 profile and; b) P - 06 profile. The gamma-ray responses are highlighted in light grey and magnetic anomalies are highlighted in light pink. 


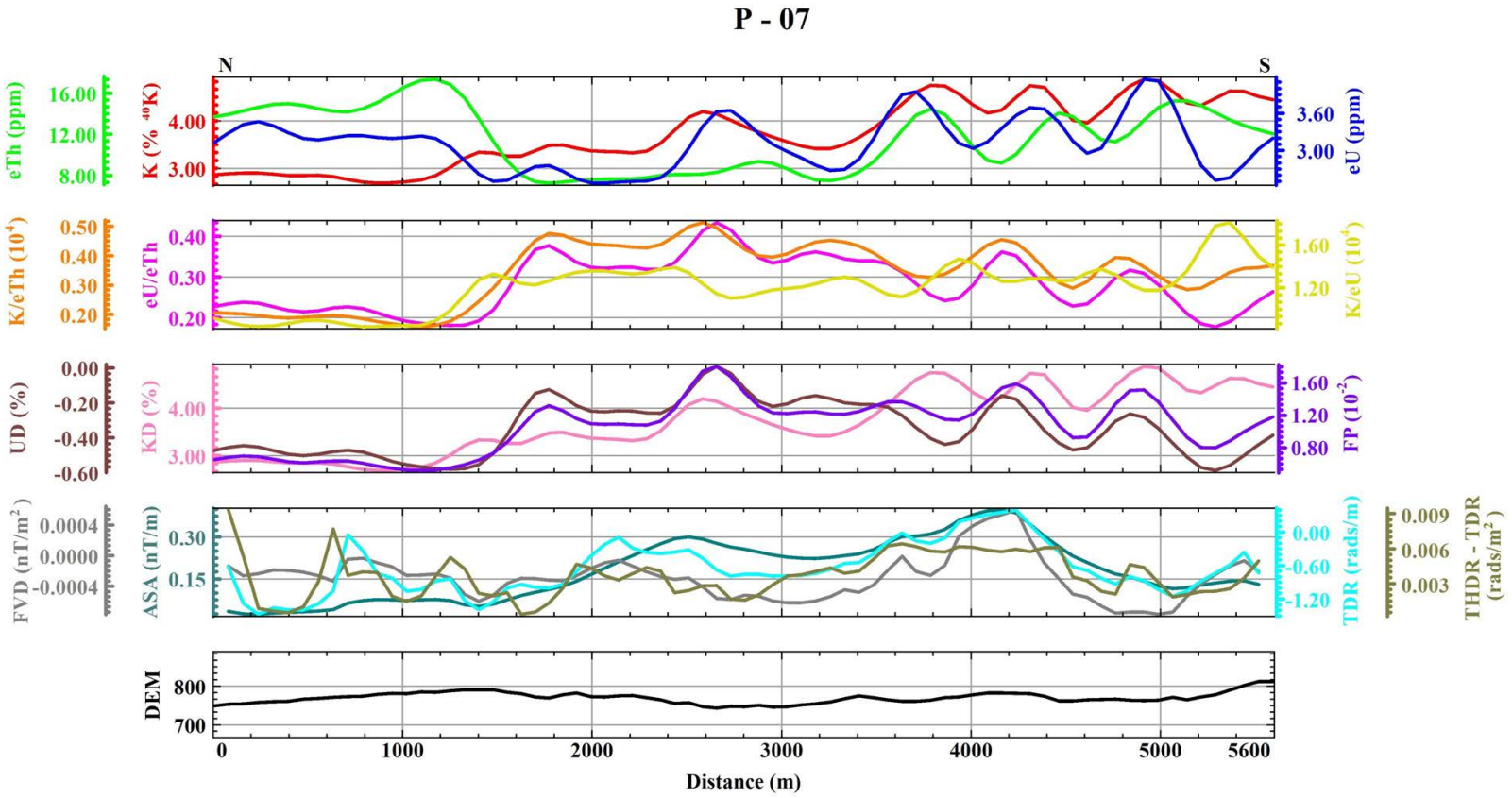

(a)
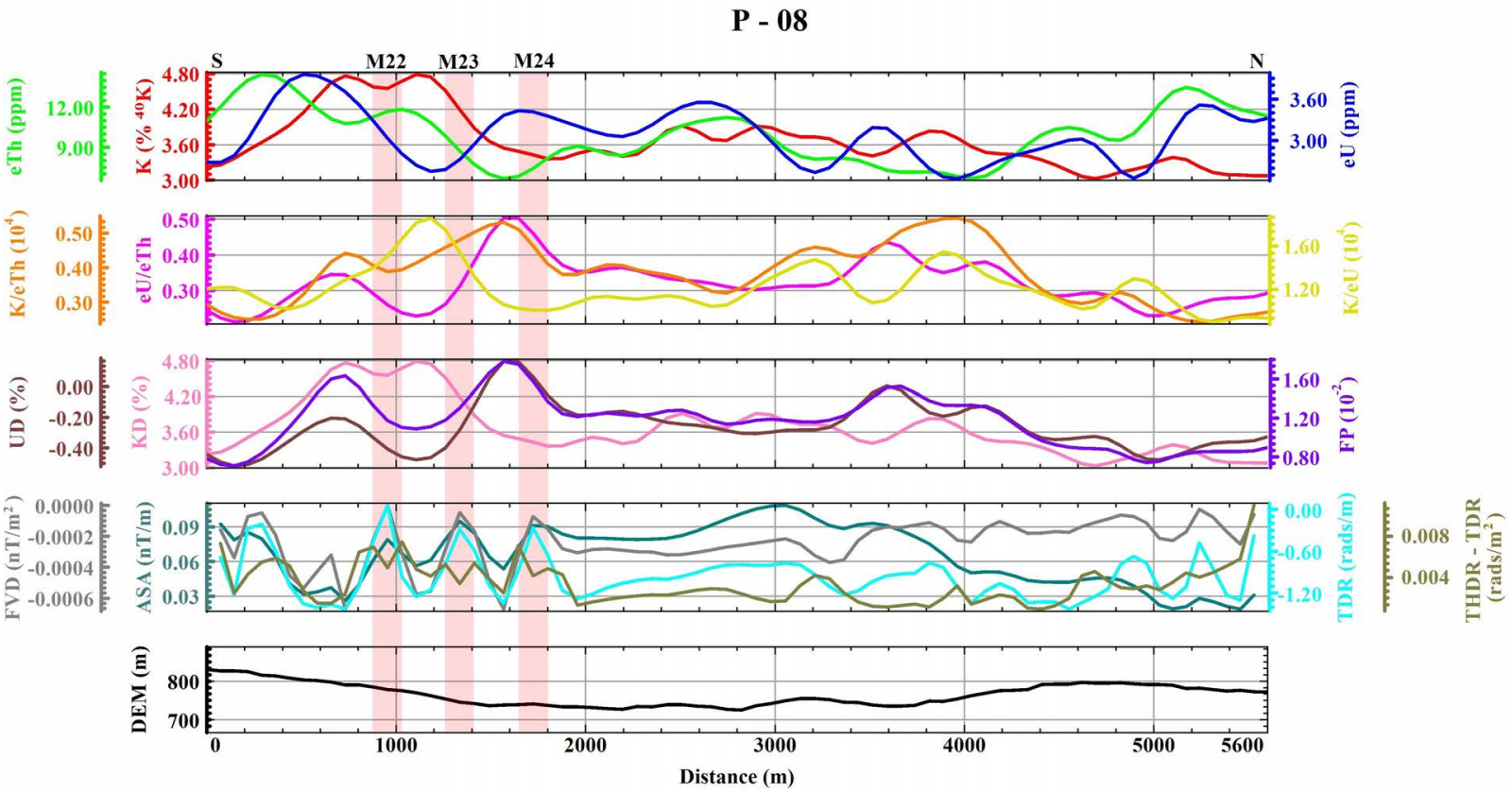

(b)

Figure 9 - Airborne geophysical responses that have been identified in: a) P - 07 profile and; b) P - 08 profile. The gamma-ray responses are highlighted in light grey and magnetic anomalies are highlighted in light pink. 


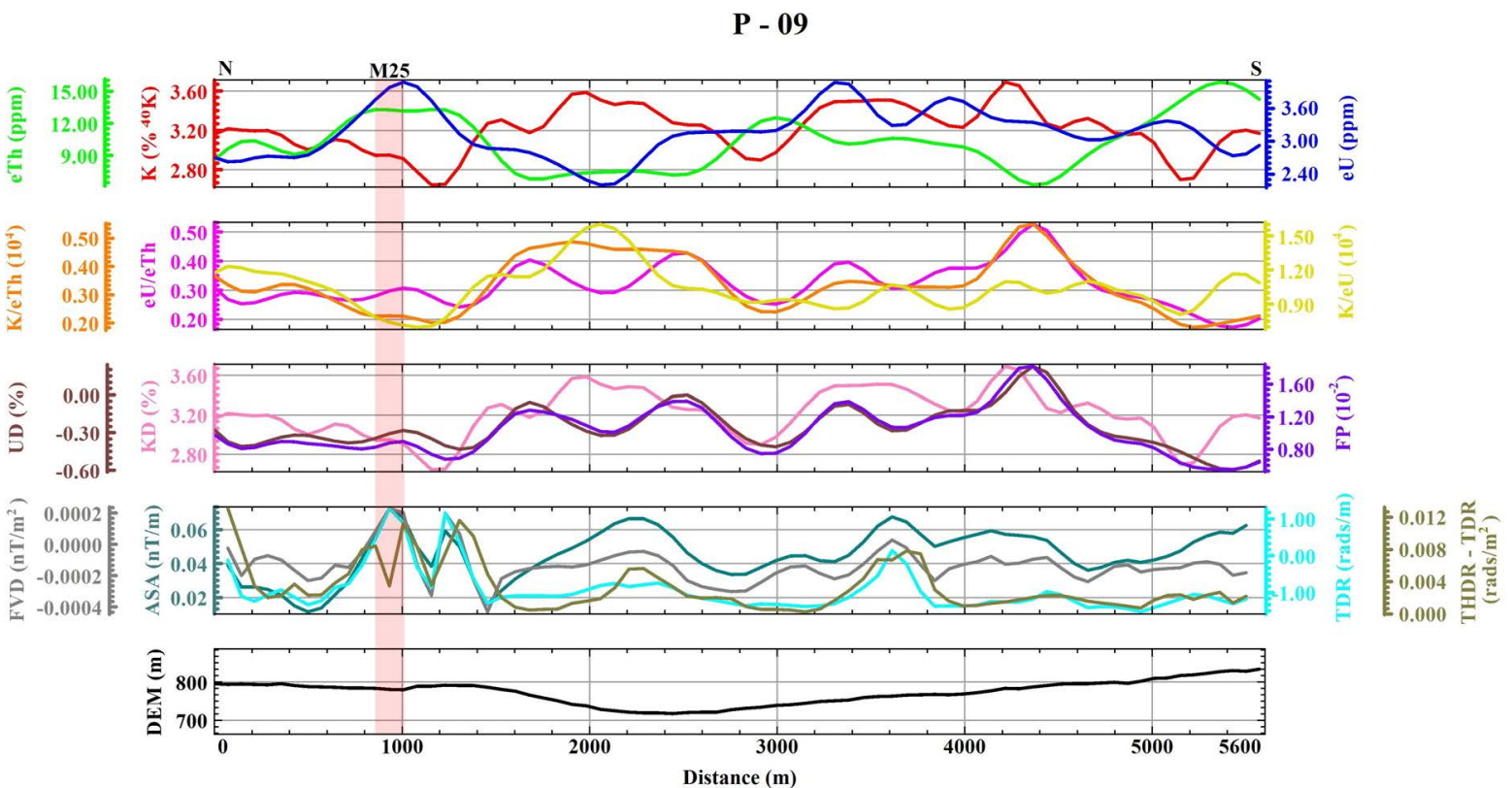

(a)

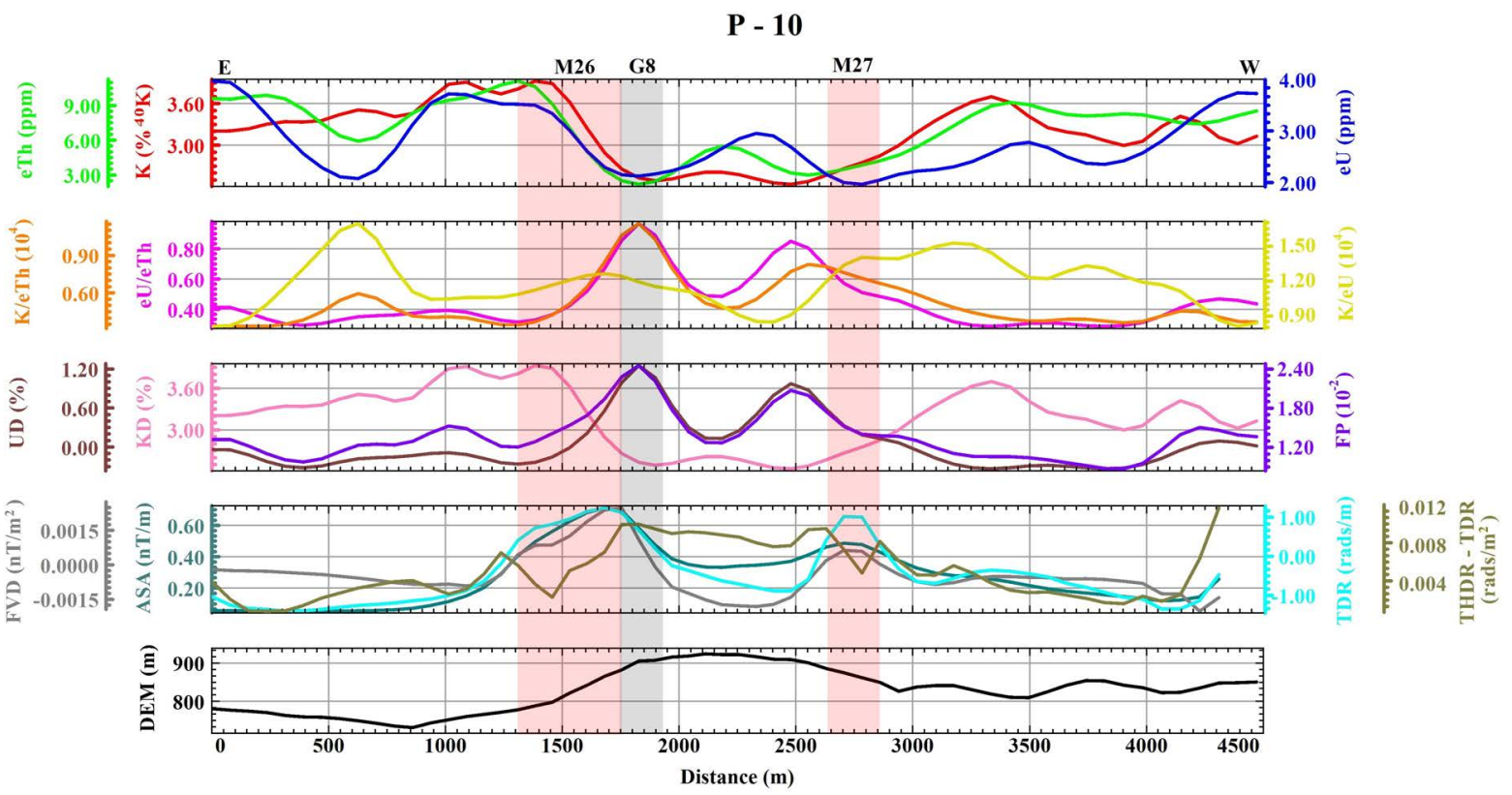

(b)

Figure 10 - Airborne geophysical responses that have been identified in: a) P - 09 profile and; b) P - 10 profile. The gamma-ray responses are highlighted in light grey and magnetic anomalies are highlighted in light pink. 


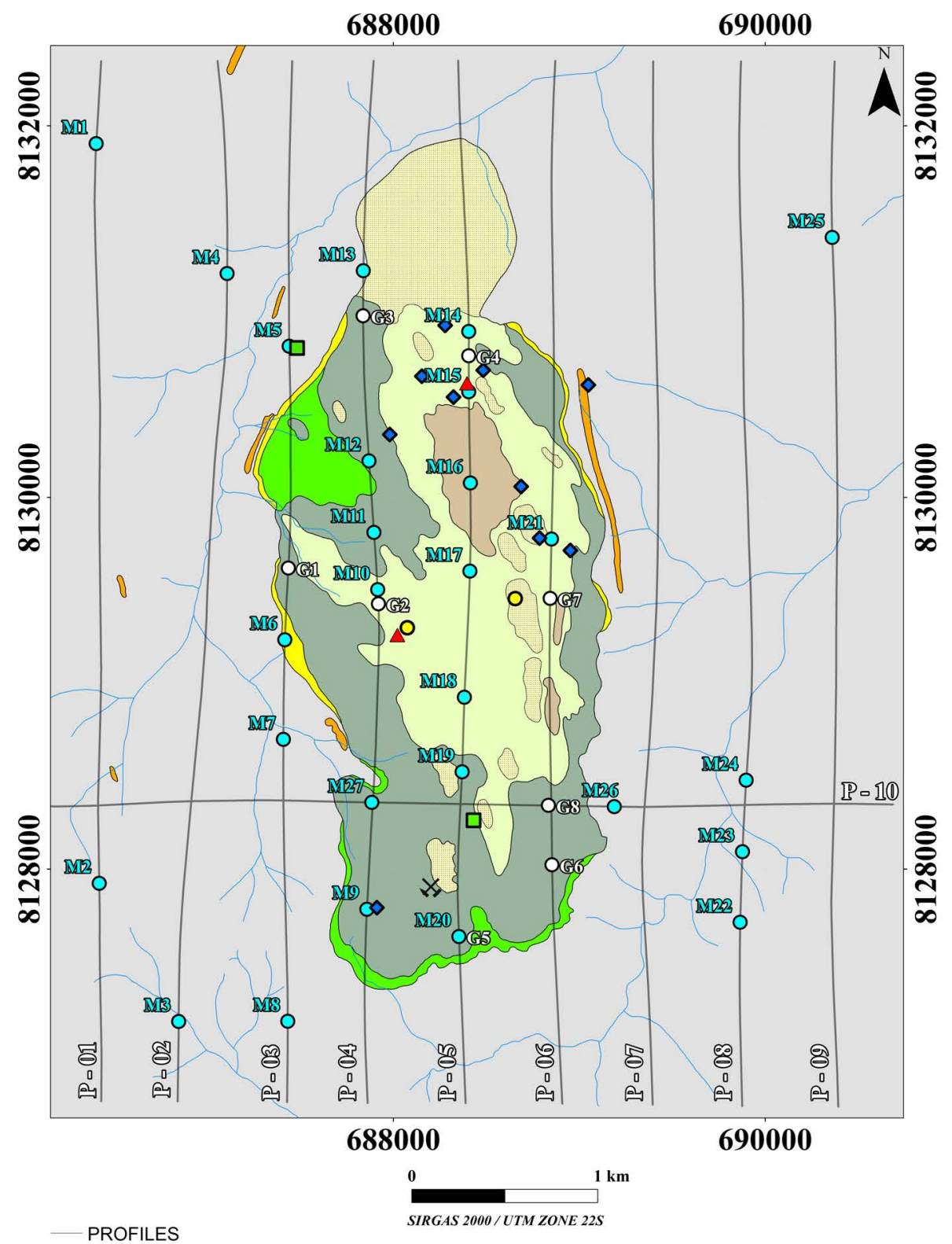

\section{ARAXÁ GROUP}

GARNET-MICA SCHIST /QUARTZ-MICA SCHIST

MICACEOUS QUARTZITE

MINERAL OCCURRENCES

$\checkmark$ CHROMITE (Cr)

O GARNIERITE (Ni)

$\triangle$ PLATINUM $(\mathrm{Pt})$

\section{ULTRAMAFIC COMPLEX}

CHROMITE'S ALLUVIUM AND ELUVIUM

$\square$ TALC

$x$, DEPLETED MINE

\section{MASSIF ULTRAMAFIC UNITS}

$\square$ A1 - ANTIGORITE SERPENTINITE
A2 - SILICIFIED SERPENTINITE
B1 - TALCIFIED SERPENTINITE
B2 - TALC SCHIST
C - CHLORITE SCHIST

AIRBORNE GEOPHYSICAL

RESPONSES

O MAGNETICS

O GAMMA - RAY

Figure 11 - MFUC geological map overlaid on DEM image with airborne geophysical responses that has been identified on the profiles plotted as point. 
To identify the magnetic anomalies, we considered the Ferreira et al.'s (2010) observations, so that we have considered magnetic anomalies the regions where the local maximum values of the ASA, FVD and TDR were in agreement with one local minimum value of the THDR-TDR and all this set being limited at both ends by approximately two local maxima values of the THDR-TDR (Fig. 5c). Taking on base the ASA, FVD and TDR peak locations, we also plotted the magnetic anomaly on the map to make associations with geological information (Fig. 11). The magnetic anomalies are more spatially distributed than gamma-ray spectrometric responses, occurring in almost all geological units. Almost half of the magnetic anomalies have been located externally to MFUC. Among the magnetic anomalies within MFUC, five (M10, M14, M15 and M18) are located in antigorite serpentinites, five (M9, M11, M12, M20 and M27) are within talcified serpentinites and one (M16) is within silicified serpentinites. No magnetic anomaly was observed within talc schist and chlorite-talc schist. However, we checked that the M6 and M12 anomalies correspond to the location of the contacts between Araxá Group and chlorite schist and between talcified serpentinite and talc schist, respectively.

The M13, M19 and M21 magnetic anomalies also occur in contact zones: in the surface deposits/Araxá Group, surface deposits/talcified serpentinite and surface deposits/antigorite serpentinite contact zones, respectively. The M12 magnetic anomaly is also close to talcified serpentinite/talc schist contact zone, but it is about $40 \mathrm{~m}$ apart it. Regarding the mineral occurrence locations, four magnetic anomalies (M5, M9, M15 and M21) practically coincide with the mineral known occurrences and one (M14) is up to $200 \mathrm{~m}$ away. The M15 anomaly draws attention because it is close to three chromite occurrences and corresponds to the local where one sample rock yielded $1210 \mathrm{ppb}$ of $P$.

Figure 12 shows the estimates results of the magnetic source depths. As it can be seen, the depths calculated by AN-EUL and SPI methods for magnetic sources identified in this study are essentially shallow $(<300 \mathrm{~m})$, except for M15 anomaly which resulted in a depth $>500 \mathrm{~m}$. The results obtained by AN-EUL were clustered by Structural Index to simplify the interpretation process.

The SPI method yields few solutions comparing to AN-EUL method (Fig. 12). Only one (M11) solution shows a depth value comparable with that obtained by AN-EUL method. For M13 and M14 anomalies, the SPI solutions yielded depth values larger than values obtained by AN-EUL method, while the opposite was found for the M3, M18 and M19 anomalies. It is worthwhile outline that, apparently, the SPI method achieved better success in to estimate the magnetic source depths outside of MFUC, mainly eastern of survey area (M22, M23, M24, M25 and M26). For M1, M4, M8, M16 and M17 it was not possible to calculate the magnetic sources depths neither by SPI nor AN-EUL methods. We believe that the absence of SPI and AN-EUL solution for these anomalies may be due to high restrict level applied in the local wavenumber and ASA peaks during to processing step.

The SED method yielded solutions with a wide range of magnetic source depths. All SED solutions are concentrated within MFUC and most of them are in the eastern boundary (Fig. 13). Figure 13 displays the spatial distributions of the SED solutions for each SI. We decided not to show the SED solutions for $\mathrm{SI}=0$ in Figure 13 because they were too few and poor.

The result shows that the solution numbers with largest depth increase as SI values (Fig. 13). Visually, the well-clustered SED solutions were obtained mainly $\mathrm{SI}=1$ and $\mathrm{SI}=2$, but the solutions for $\mathrm{SI}=3$ are more scattered than the others. In general, the best solution clusters occurs close to M14, M15, M21 and M26 anomalies. For SI = 1, solutions well-clustered occur eastern M14, southeastern M21 and southwestern M26. For these clusters, the magnetic sources are mainly concentered in shallow depth $(<250 \mathrm{~m})$, but largest values $(250-500 \mathrm{~m})$ are obtained in the southwestern M26. For $\mathrm{SI}=2$, the best solutions occur near to southwestern M14 and close to M15 and M21 anomalies. The depths estimated are around to $250-500 \mathrm{~m}$ for M14 and M21 anomalies and 500-750 m for M15 anomaly. Solutions within 500-750 depth range also occur to southwest M26, but these appear to be more scattered.

\section{DISCUSSION}

The results described evidences of the existence of airborne geophysical responses within and around MFUC. If we have analyzed only $K$, eU and $e T h$ concentrations maps, we would have found difficult to interpret the G1 - G8 responses. Besides that, the interpretation of the magnetic anomalies would be harder if we have considered only AMF and/or ASA maps. Considering the airborne gamma-ray data, the option for no removing the negative values was essential because became possible to view the radiometric ratios. Moreover, for airborne magnetic data, the correlation among of the ASA, FVD, TDR and THDR-TDR made it easier to identify the magnetic anomalies.

The radiometric ratios are very useful because they suppress several effects, such as soil mixture and geometry 


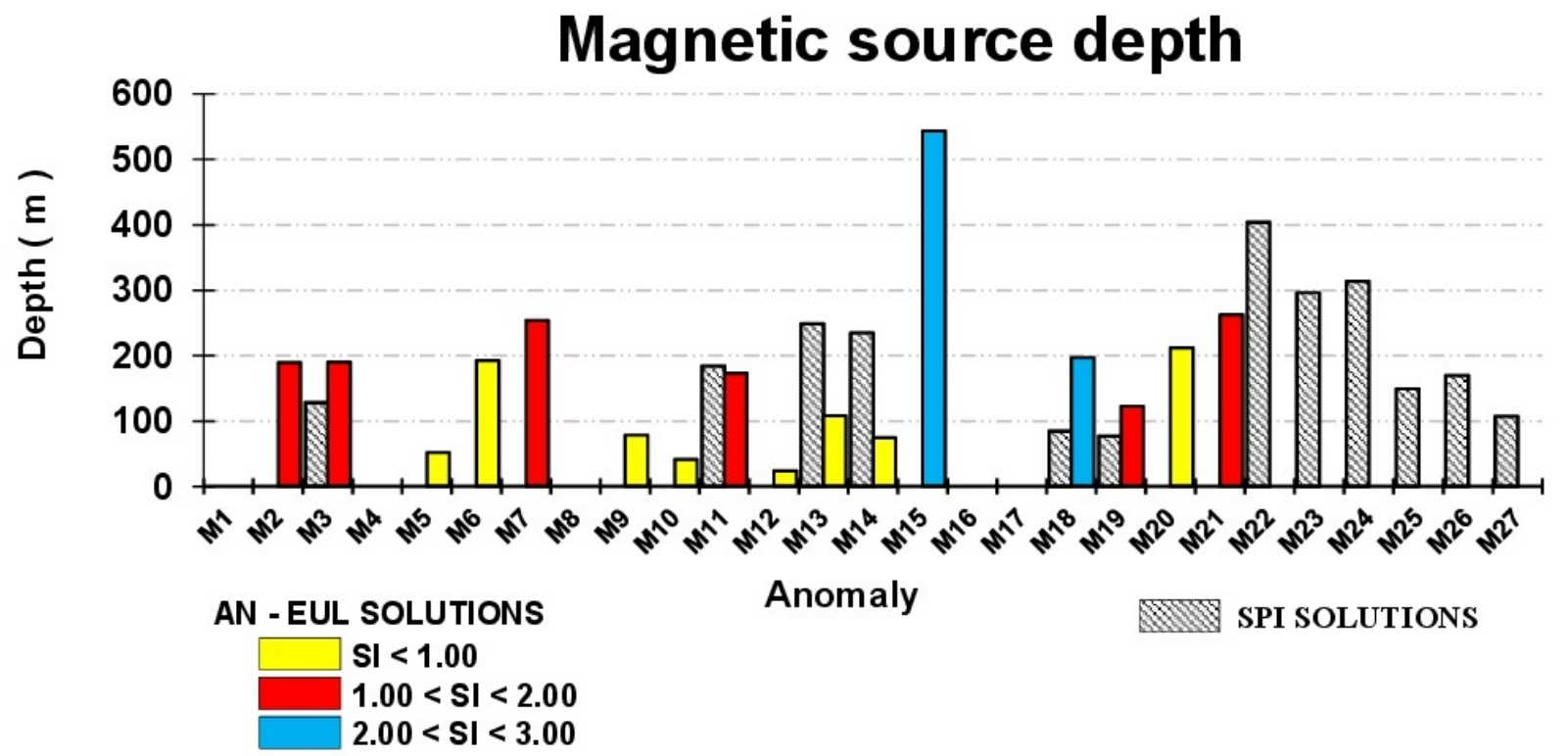

Figure 12 - Estimative of magnetic source depths obtained by AN-EUL and SPI method.

detecting, and highlight subtle variations, providing a measurement of relative enrichment between radioelements, so that this enrichment may be an indicative for mineralization or rock alterations (IAEA, 2003). Furthermore, some hydrothermal alterations indexes, like KD, UD and FP, may be useful in the mineralized zones mapping. The KD and UD express loss or gain of the $K$ and $e U$, respectively, in relation to background estimated from the $K$ and $e U$ normalizations by $e T h$ concentrations. This normalization takes in account that any event that affects $T h$ abundances would also affect $K$ and $U$ abundances because $T h$ is less mobile than $K$ and $U$ elements. So, Th concentration can be used as lithological control, therefore, the $K$ and/or $U$ concentrations of a lithological unit may be estimated from $T h$ concentrations. This is possible because there is a dependency relation between $K$ and $T h$ and between $U$ and $T h$ for many rocks (Galbraith \& Saunders, 1983). The Kand/or eU values obtained by these relations would represent "ideal values", that is, they represent the $K$ and/or eU distributions that are expected in the absence of remobilizations process. The difference between the observed data and this "ideal values" are interpreted as anomalous values (KD and/or UD). The areas with $K D$ and/or UD high values are potential targets for mineral prospecting, because they may indicate hydrothermally modified rocks.

Potential areas for mineral prospecting may also be identified by FP index. Basically, FP index expresses the $\mathrm{Kand}$ eU product divided by eTh (Efimov, 1978 apud Gnojek \& Prichystal, 1985). Rocks extremely altered hydrothermally show FP high values (Gnojek \& Prichystal, 1985). This occurs because the hydrothermal fluids commonly contain $K$ and, sometimes, $U$ dissolved. When these fluids find a geochemistry barrier, Kand/or Uare accumulated, increasing their concentrations in the rock but without substantial rise of Th (Ostrovskiy, 1975). In this context, a peak correlation of the K/eTh, eU/eTh, FP is expected, and also KD and UD curves, because hydrothermal fluids may change the local $K$ and/or Udistributions and this change may be characterized by $K$ and/or eU excess.

In our result, all gamma-ray spectrometry responses (G1 - G8) are characterized by an eTh decline. Furthermore, all of them occur within massive ultramafic and on steep relief. In the places where the topography is steep, the erosion process is predominant, so that the gamma-ray spectrometric response is directly related to minerals and geochemistry of fresh rock or secondary minerals from hydrothermal alteration processes (Wildfort et al., 1997). The first case seems to be the explanation for G1, G3, G5, G6, G7 and G8 responses and the last seems to be the explanation for $\mathrm{G} 2$ and $\mathrm{G} 4$ responses.

In the first case, the results show that G1, G3, G5, G6, G7 and G8 areas are characterized by an increase in the eU/eTh, FP and UD curves. As previous mentioned, subduction-related serpentinites may show high U/Th ratios due the action of fluids 


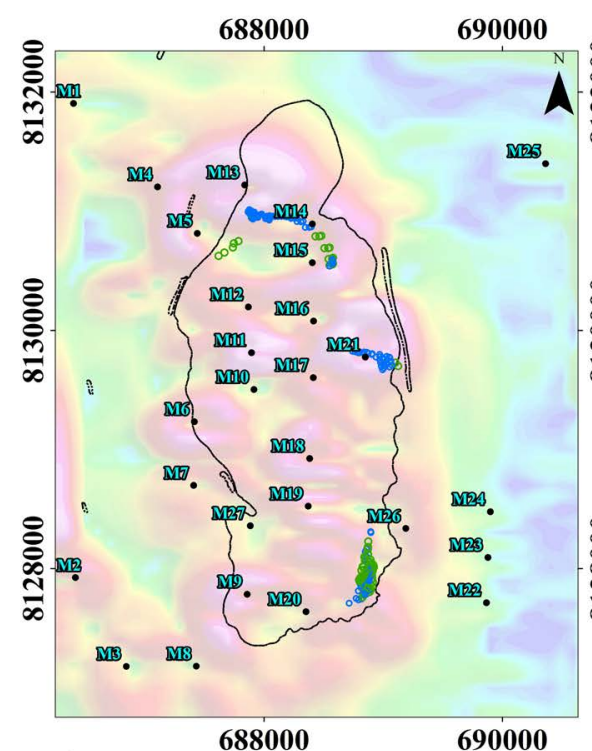

a)

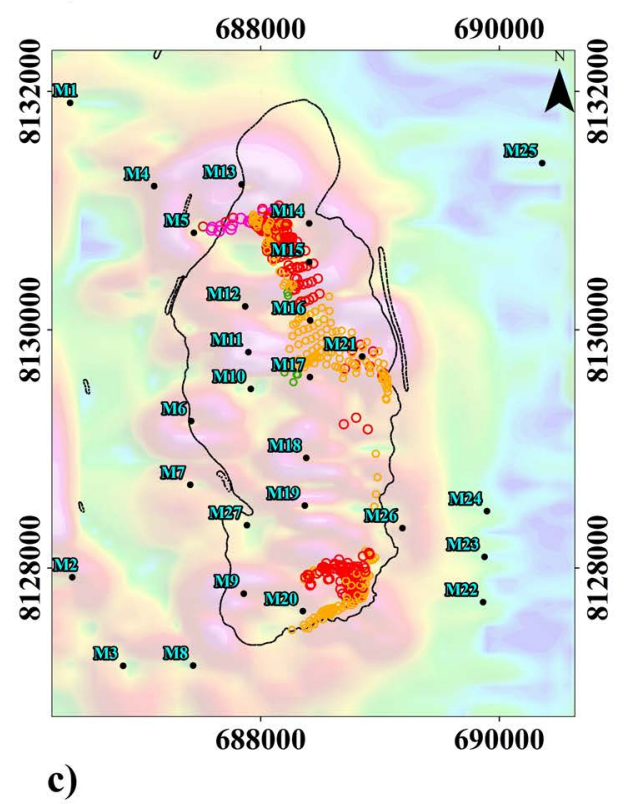

b)
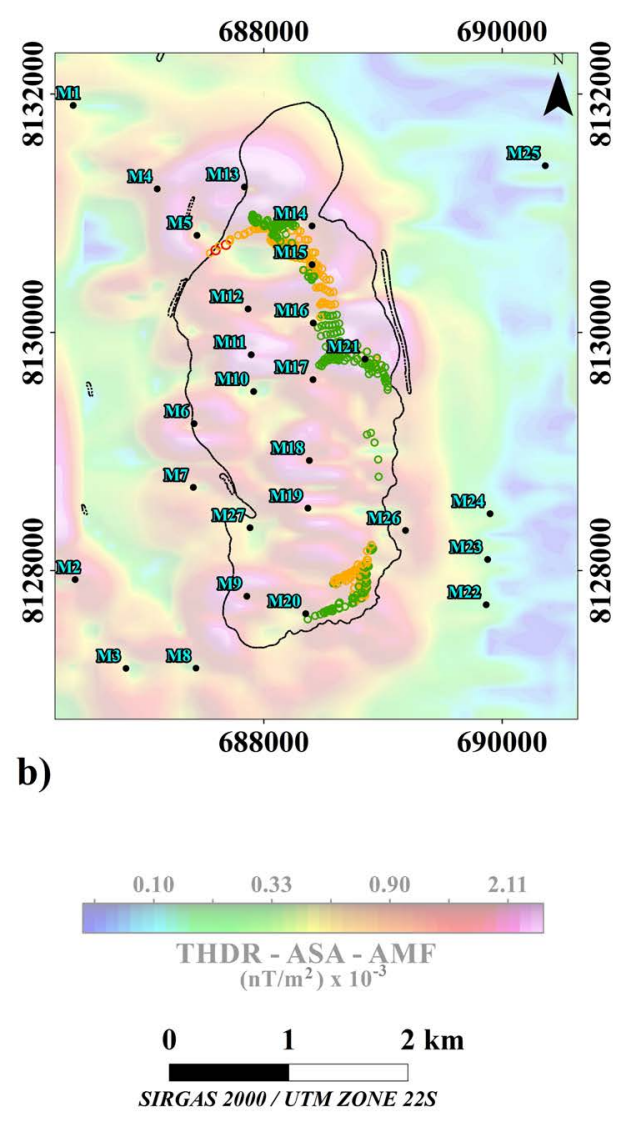

- MAGNETIC ANOMALIES

\section{DEPTH RANGES}

$\circ<250 \mathrm{~m}$

○ $250-500 \mathrm{~m}$

○ $500-750 \mathrm{~m}$

O $750-1000 \mathrm{~m}$

$\mathrm{O}>1000 \mathrm{~m}$

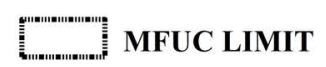

Figure 13 - Spatial distribution of SED solutions with the depth ranges obtained considering: a) $\mathrm{SI}=1$; b) $\mathrm{SI}=2$ and $\mathrm{SI}=3$.

during hydration process (Deschamps et al., 2013). We suggest that the sources of the gamma-ray spectrometry responses in questions may be related to serpentinites. This idea implies that UD peaks could also be from serpentinites. The same seems the case for FP index, that is, the FP index high values reflect the gamma-ray responses from serpentinites. Unfortunately, we have not carried out field survey to confirm if high eU/eTh ratios are really from serpentinites, but the results let us affirm that airborne gamma-ray spectrometry data are able to detect such ratio in serpentinized ultramafic terrain. We suggest the accomplishment of other researches focused on verifying if this $\mathrm{eU} / \mathrm{eTh}$ ratio is from serpentinites. A possible positive result from these researches may open a new perspective for the use for eU/eTh ratio applied as a tool aid in the serpentinites mapping.

For the G2 and G4, the results show that, besides these regions are characterized by increase in the eU/eTh, K/eTh, FP 
and UD curve, they are also characterized by a soft increase in the $\mathrm{K} / \mathrm{e} U$ and $\mathrm{KD}$ curves. This suggests that in these regions there are $K$ enrichment in detriment of $e U$ and $e T h$. Here, we suggest the eU/eTh and UD peaks may be from serpentinite but it is not the source for Kenrichment observed. Airo (2002) observes that mafic rocks commonly have low $K$ counts, even undetectable. The author points out that, in the analysis of flight lines, the increase of the $K$ content in accordance with the increase of the K/eTh ratio may be indicative of some alteration process, thus making areas promising for prospecting. The fact that G2 and G4 are less than $200 \mathrm{~m}$ apart from platinum, chromite and garnierite occurrence reinforce the potentiality of these areas for mineral prospecting that would be performed by others studies.

From the airborne gamma-ray spectrometry data processing, it was identified geophysical responses possibly related to the lithology and hydrothermal alteration. However, these responses are restricted to surface. The information about sources in depth was provided by airborne magnetic data.

As seen in the previous section, the depth values were obtained from the three different methods. Due to the way each method works, we expected some differences in the depth values, but these values are in agreement with what we would expect from each method. Since SPI and AN-EUL method estimates the magnetic sources depth from the higher order derivative, we would expect shallowest depth values for both methods (Li, 2003). Our results are in agreement to this observation because they show that most of magnetic sources depths estimated by SPI and AN-EUL methods, with exception M15 and M22, are up to $300 \mathrm{~m}$.

The difference in the depth values between SPI and AN-EUL may be explained due to the model that each method takes on. In the software used in this work, the SPI method takes into account a step-type source, while AN-EUL method, the magnetic source that may have other and more complex geometries depending of SI calculated. In other words, the magnetic source model is defined a priori in the SPI model, but in the AN-EUL it is defined a posteriori, which makes it possible to model a wider range of magnetic sources. However, based on geological knowledge, we believe that the SPI solutions may be more coherent externally to MFUC, while the AN-EUL solutions may be more coherent inside to MFUC.

Externally to MFUC, the M22, M23, M24 and M26 magnetic anomalies occur in places where the lithology is dominated mainly by garnet-mica schist with micaceous quartzite lenses that are essentially nonmagnetic. Based on SPI solutions, we suggest that the magnetic sources for these anomalies may be due to structural features, like a fault or fracture, in depth up to 400 m. However, the AN-EUL solutions for M2, M3 and, possibly, M7, may be the magnetic responses from dikes in depth up to $250 \mathrm{~m}$. These dikes were mapped by Berbert \& Mello (1969) and correspond to a small linear segment of the mafic bodies form the Azimuth $125^{\circ}$ lineament. The calculated SI values agree to SI values adopted by Moraes Rocha et al. (2014). The M7 anomaly may be the magnetic response of a dike in depth that has no expression on the surface.

Internally to MFUC, the AN-EUL solutions were consistent for M6, M12 and M13. Based on AN-EUL solutions, the M6 and M12 anomalies may be the magnetic response from Araxá Group/chlorite schist contact at $200 \mathrm{~m}$ of depth and talcified serpentinite/talc schist contact zones at less than $100 \mathrm{~m}$ of depth, respectively. On the map, the M13 anomaly coincides with a contact region between surface deposits and garnet-mica schist. Once the surface deposits are nonmagnetic, we believe that M13 anomaly may be due to the garnet-mica schist/ultramafic contact in $100 \mathrm{~m}$ of depth. On the other hand, the M19 and M21 anomalies coincide with contact zones, but the AN-EUL method yielded solutions for dike model. In this case, we understand the contact zones become structures more complex as depth increase, which may suggest the existence of magnetic sources in depth.

AN-EUL solutions for the M5, M9, M10 and M20 anomalies also provided a contact-type source model. When plotted on the map, the M5 anomaly falls within garnet-mica schist and coincides with talc occurrences, while M9 and M14 fall within MFUC and are very close to chromite occurrences. Since the garnet-mica schist is weakly magnetic, M5 may be due to garnet-mica schist/ultramafic contact zone in depth $(<100$ $\mathrm{m})$. The M9 and possibly M10 and M20 anomalies may be the magnetic responses of susceptibility contrast between the different MFUC units in depth.

As seen before, the M15 and M18 are the only anomalies which AN-EUL solutions yielded a more complex magnetic source model, with $2<\mathrm{SI}<3$. However, it is noted that the depth of M18 anomaly is shallower than M15 anomaly and we have not identified any magnetic sources in depth by SED method. So, we believe that AN-EUL solutions for M15 reinforce the existence of complex magnetic sources in depth. Our results show that SED solutions have given the most support for the existence of this deepest magnetic source.

The SED solutions make use of the first derivative order and moving windows. The use of large moving windows in this work 
yielded few and well-clustered solutions, which have facilitated the interpretation process (Uieda et al., 2014). Meanwhile, large moving windows may be affect the results due to anomaly superpositions effects, so that SED solutions may not coincide exactly with the positions of magnetic anomalies that we have found in this work. However, we have identified solutions clustered close to M14, M15, M21 and M26 anomalies.

Near to M14 anomaly, we have identified two magnetic sources clusters with solutions well-clustered for $<250 \mathrm{~m}$ and 250-500 $\mathrm{m}$ depth ranges, considering $\mathrm{SI}=1$ and $\mathrm{SI}=2$, respectively. AN-EUL solutions provided a different magnetic model $(\mathrm{SI}<1)$ and a shallowest depth value $(<100 \mathrm{~m})$ for this same anomaly. In our interpretation, the shallowest depth given by AN-EUL and SED $(S I=1)$ solutions are relatively in agreement and may be, in fact, related to the magnetic source from M14 anomaly. However, for this same anomaly, the deepest solutions given by $\mathrm{SI}=2$ may be related to increase in the estimation of depth value due to an overestimated choice of the SI value (Uieda et al., 2014). The depth values estimated for M15 anomaly by SED solutions ( $\mathrm{SI}=2$ and $500-750 \mathrm{~m}$ ) are in agreement to AN-EUL results $(2<\mathrm{SI}<3$ and $\sim 540 \mathrm{~m})$. The same agreement of values has been observed for M21 anomaly (AN-EUL: $0<\mathrm{SI}<1$ and $260 \mathrm{~m}$; SED: $\mathrm{SI}=2$ and $250-500 \mathrm{~m}$ ). These results reinforce the evidence of deep magnetic source within MFUC. It is worthwhile outline that M15 and M21 anomalies occur in central-north portion of the ultramafic massif that Milliotti (1978) stressed as the richest in participation of Pt. The fact that Pt and chromite occurrences coincide with M15 and M21 anomalies location reinforce the Berbert \& Mello's (1969) arguments about the existence of $P t$, Crand Ni primary sources in depth.

\section{CONCLUSIONS}

From the discussion above, we conclude that the present study has achieved its goal by identifying the magnetic and airborne gamma-ray spectrometry responses within and around of MFUC. From the profile analysis, we have identified twenty seven magnetic anomalies and eight gamma-ray spectrometry responses.

The magnetic anomalies can be partitioned in shallow $(<$ $300 \mathrm{~m})$ and deep ( $500 \mathrm{~m})$ sources. Based on works that have been published and taking in account our results, we conclude the shallowest magnetic anomalies are related dikes, contact zones and other structures, while the deepest magnetic anomalies have complex geometries and are concentrated in central-western MFUC, where the participation of Pt is large. In this aspect, we can conclude that the existence of $P t, \mathrm{Cr}$ and Niprimary sources in depth is possible, so that our results reinforce the Berbert \& Mello's (1969) arguments.

Regarding the airborne gamma-ray spectrometry responses, we have identified not just relatively high eU/eThratio, but also K/eTh and K/eU proportions that are softly increased within ultramafic complex. Since we did not make the follow up of these gamma-ray responses, we can only conclude that airborne gamma-ray spectrometry may detect relatively high eU/eTh ratio in ultramafic complexes, but remains open to know if these eU/eTh ratios are really from serpentinites. It is also open to know the source for softly increased K/eTh and $\mathrm{K} / \mathrm{eU}$ ratios. Considering that $K$ low values would be expected in ultramafic rocks and that softly increased $\mathrm{K} / \mathrm{eTh}$ and $\mathrm{K} / \mathrm{e} U$ ratios identified in this work are near to mineral occurrences, we concluded such responses may be seen as evidence of hydrothermal alteration processes. Finally, we hope that the results of our study can complement previous studies that were performed about MFUC.

\section{ACKNOWLEDGMENTS}

The authors are grateful to the Remote Sensing and Geophysics Division of the Geological Survey of Brazil for providing the aerogeophysical data that were used in the present work. The authors are also thankful for reviewers by corrections and observations suggested. Such contributions were essential both for this study and our learning.

\section{REFERENCES}

AIRO ML. 2002. Aeromagnetic and Aeroradiometric Response to Hydrothermal Alteration. Surveys in Geophysics, 23: 273-302.

ANGELIM LAA, DELGADO IM, GOMES IP, GUIMARÃES JT, HEINECK CA, LACERDA FILHO JV, PERROTA MM, SANTOS RA, SILVA LC, SILVA AJP, SILVEIRA FILHO NC, SOUZA JD, VALENTE CR \& VASCONCELOS AM. 2003. Província Tocantins. In: BIZZI LA, SCHOBBENHAUS C, VIDOTTI RM \& GONÇALVES JH (Org.). Geologia, Tectônica e Recursos Minerais do Brasil: Texts, Maps \& GIS, Companhia de Pesquisa de Recursos Minerais/Serviço Geológico do Brasil. Cap. V.

BLAKELY RJ \& SIMPSON RW. 1986. Approximating edges of source bodies from magnetic or gravity anomalies. Geophysics, 51(7): 1494-1498.

BERBERT CO. 1977. Complexos máfico/ultramáficos no Brasil. In: I Simpósio de Geologia Regional, Atas. São Paulo (SP), Brazil: SBG, p. $4-28$.

BERBERT CO \& MELLO JCR. 1969. Investigação geológica-econômica da área de Morro Feio - Hidrolândia, Goiás, Brazil: DNPM/DFPM, Bol. № $132,81 \mathrm{pp}$. 
BILLINGS SD \& RICHARDS D. 2001. Quality control of gridded aeromagnetic data. Exploration Geophysics, 31: 611-616.

BRIGGS IC. 1974. Machine Contouring using Minimum Curvature. Geophysics, 39(1): 39-48.

CASTROVIEJO R. 2004. El oro en ofiolitas. In: PEREIRA E, CASTROVIEJO R \& ORTIZ F (Eds.). Complejos Ofiolíticos em Iberoamérica: guías de prospeccíon para metales preciosos. Madrid: Rede CYTED. Cap. 2: 25-69.

COLEMAN RG. 1977. Ophiolites: Ancient Oceanic Lithosphere? Mineral and Rocks, 12, Springer - Verlag, 229 pp.

DARDENNE MA. 2000. The Brasília Fold Belt. In: CORDANI UG, MILANI EJ, THOMAZ FILHO A, CAMPOS NETO DA (Eds.). Tectonic Evolution of South America. Rio de Janeiro, Brazil: 31st. IGC, 231-263.

DESCHAMPS F, GODARD M, GUILLOT S \& HATTORI K. 2013. Geochemistry of subduction zone serpentinite. Lithos, 178: 96-127.

EFIMOV AV. 1978. Multiplikativnyj pokazatel dlja vydelenija endogennych rud aerogamma-spectrometriceskim dannym, in Metody rudnoj geofiziki: Lenigrad, Naucno-proizvodstvennoje objedinenie Geofizica Ed., p. 59-68.

FERREIRA FJ, SOUZA J, BONGIOLO ABS, CASTRO LG \& ROMEIRO MAT. 2010. Realce do gradiente horizontal total de anomalias magnéticas usando a inclinação sinal analítico. Parte I - Aplicação a dados sintéticos. In: IV Simpósio Brasileiro de Geofísica. Brasília, DF, Brazil: SBGf.

GALBRAITH JH \& SAUNDERS DF. 1983. Rock classification by characteristics of aerial gamma-ray measurements, Journal of Geochemical Exploration, 18: 49-73.

GEOSGB. 2018. Mineral Resources from Brazil [database], Geological Survey of Brazil. Available on: <http://geowebapp.cprm.gov.br/ ViewerWEB/index Łrecmin.html>. Access on: January 1, 2018.

GNOJEK I \& PRICHYSTAL A. 1985. A new zinc mineralization detected by airborne gamma-ray spectrometry in Northern Moravia (Czechoslovakia). Geoexploration, 28: 491-502.

GRANT JA. 1998. Ten things the textbooks don't tell you about processing and archiving airborne gamma-ray spectrometric data. Geological Survey of Canada, Current Research, 1998-D: 83-87.

IAEA. 2003. Guidelines for radioelement mapping using gamma-ray spectrometry data. IAEA, Vienna, Austria, 179 pp.

LASA ENGENHARIA E PROSPECÇÕES S.A. 2005. Projeto Levantamento Aerogeofísico do Estado de Goiás - $2^{\text {a }}$ Etapa - Faixa Brasília Sul - Relatório Final do Levantamento e Processamento dos dados magnetométricos e gamaespectrométricos. Convênio de Cooperação Técnica entre a SGM/MME/CPRM e SIC/SGM/FUNMINERAL/Estado de Goiás, Final Report, 12 vol., Texts and Maps, Rio de Janeiro, Brazil.
LI X. 2003. On the use of different methods for estimating magnetic depth. The Leading Edge, 22(11): 1090-1099.

MACLOAD IN, JONES K \& DAI TF. 1993. 3D Analytical signal in the interpretation of total magnetic fields data at low magnetics latitudes. Exploration Geophysics, 24; 679-688.

MANTOVANI MSM \& BRITO NEVES BB. 2009. The Paranapanema lithospheric block: its nature and role in the accretion of Gondwana. In: GAUCHER C, SIAL AN, HALVERSON GP \& FRIMMEL HE (Eds.). Neoproterozoic Cambrian Tectonics, Global Change and Evolution: a focus on southwestern Gondwana. Developments in Precambrian Geology, 16: 257-272.

MILLER HG \& SINGH V. 1994. Potential field tilt - A new concept for location of potential field sources. Journal of Applied Geophysics, 32(2-3): 213-217.

MILLIOTTI CA. 1978. Distribuição e controles da mineralização de platina no Morro Feio - GO. Master Dissertation, Universidade de Brasília, DF, Brazil. 149 pp.

MRDS. 2018. Mineral Resources Data System [database]. United States Geological Survey (USGS). Available on: <https://mrdata.usgs.gov/ mrds/show--mrds.php?dep Lid=10279692>. Access on: January 15, 2018.

MORAES ROCHA LG, PIRES ACB, CARMELO AC \& ARAÚJO FILHO J0. 2014. Geophysical characterization of the Azimuth $125^{\circ}$ lineament with aeromagnetic data: Contributions to the geology of central Brazil. Precambrian Research, 249: 273-287.

NABIGHIAN MN. 1972. The analytic signal of two-dimensional magnetic bodies with polygonal cross-section: Its properties and use for automated anomaly interpretation. Geophysics, 37(3): 507-517.

OSTROVSKIY EYA. 1975. Antagonism of radioactive elements in wallrock alterations fields and its use in aerogamma spectrometric prospecting. International Geology Review, 17(4): 461-468.

PIRES ACB. 1995. Identificação geofísica de áreas de alteração hidrotermal, Crixás - Guarinos, Goiás. Revista Brasileira de Geociências, 25(1): 61-68.

QUEIROGA GN, SUITA MTF, PEDROSA-SOARES AC, MARTINS MS \& PINHEIRO MAP. 2012. Síntese sobre ofiolitos: evolução dos conceitos. Rem: Revista Escola de Minas, 65(1): 47-58.

REEVES C. 2005. Aeromagnetic Surveys: Principles, Practice \& Interpretation. Earthworks, Geosoft: Cap 6, 6-18.

REID AB, ALLSOP JM, GRANSER H, MILLETT AJ \& SOMERTON IW. 1990. Magnetic interpretation in three dimensions using Euler deconvolution. Geophysics, 55(1): 80-91.

ROEST WR, VERHOEF J \& PILKINGTON M. 1992. Magnetic interpretation using the 3-D analytic signal. Geophysics, 57: 116-125. 
SALEM A \& RAVAT D. 2003. A combined analytic signal and Euler method (AN-EUL) for automatic interpretation of magnetic data. Geophysics, 68(6): 1952-1961.

SAUNDERS D, TERRY AS \& THOMPSON CK. 1987. Test of National uranium Resource Evaluation gamma-ray spectral data in petroleum reconnaissance. Geophysics, 52(11): 1547-1556.

STRIEDER AJ \& NILSON AA. 1992a. Melange ofiolítica nos metassedimentos Araxá de Abadiânia (G0) e implicações tectônicas regionais. Revista Brasileira de Geociências, 22(2): 204-215.

STRIEDER AJ \& NILSON AA. 1992b. Estudo petrológicos de alguns fragmentos tectônicos da melange ofiolítica em Abadiânia (G0): I - 0 protolito dos corpos de serpentinito. Revista Brasileira de Geociências, 22(3): 338-352.

THURSTON JB \& SMITH RS. 1997. Automatic conversion of magnetic data to depth, dip, and susceptibility contrast using the SPITM method.
Geophysics, 62(3): 807-813.

UIEDA L, OLIVEIRA JUNIOR VC \& BARBOSA VCF. 2014. Geophysical tutorial: Euler deconvolution of potential-field data. The Leading Edge, 33: 448-450.

VALENTE CR. 1986. Projeto mapas metalogenéticos e de previsão de recursos minerais: Goiânia, Folha SE. 22-X-B. Brasília, Brazil, Convênio DNPM/CPRM, 14 pp.

VERDUZCO B, FAIRHEAD JD, GREEN CM \& MACKENZIE C. 2004. New insights into magnetic derivatives for structural mapping. The Leading Edge, 23: 116-119.

WILDFORT JR, BIERWIRTH PN \& CRAIG MA. 1997. Application of airborne gamma-ray spectrometry in soil/regolith mapping and applied geomorphology. Journal of Australian Geology \& Geophysics, 17(2): 201-216. 